A product of the USGS National Water Census and the USGS National Streamflow Information Program

\title{
Withdrawal and Consumption of Water by Thermoelectric Power Plants in the United States, 2010
}

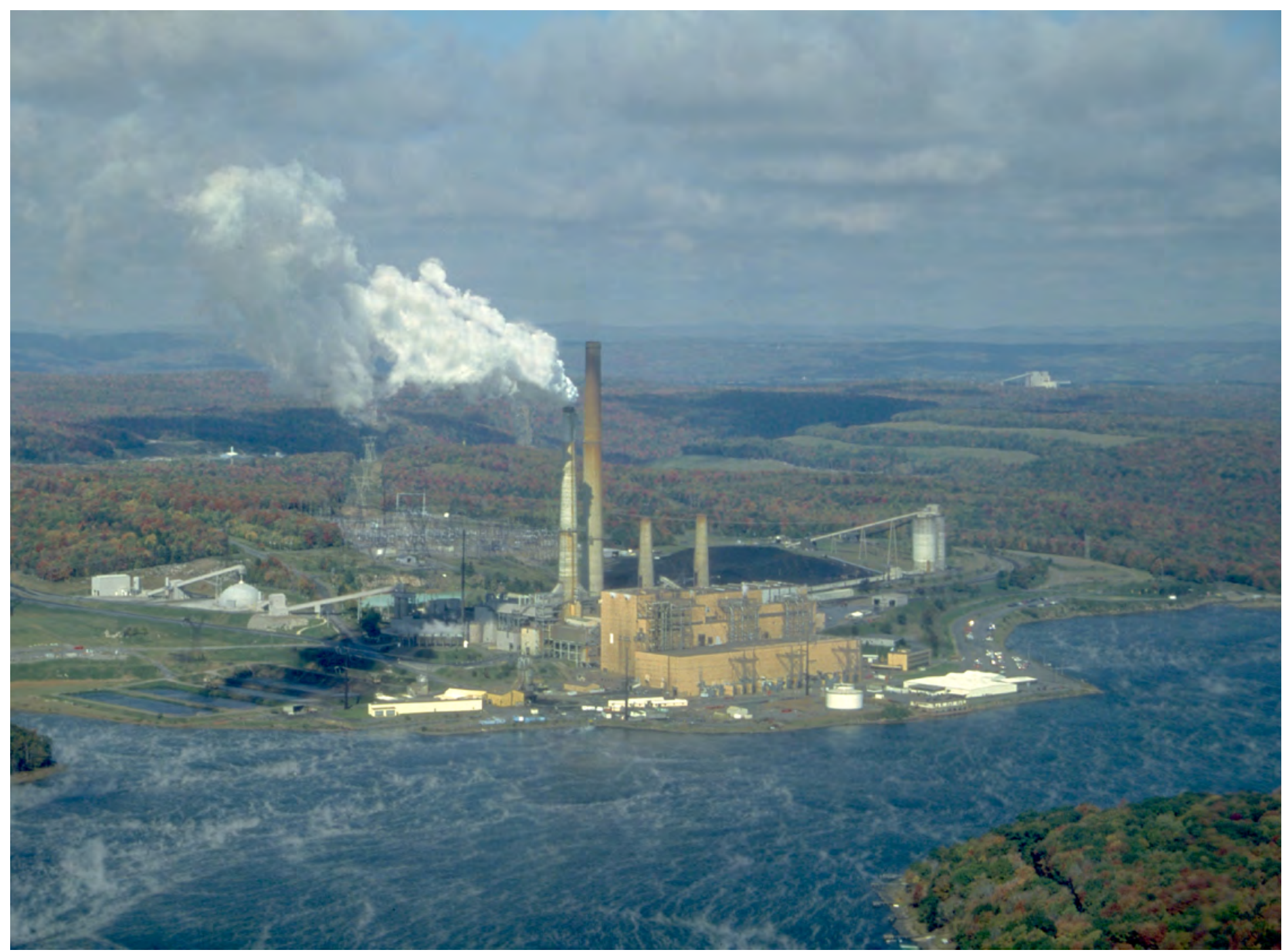

Scientific Investigations Report 2014-5184 
Cover photograph. Steam rising from the once-through cooling reservoir of the coal-fired Mount Storm Power Station in Grant County, West Virginia, owned by Dominion Resources, Inc. Photograph by Raeky [Public Domain], via Wikimedia Commons. 


\section{Withdrawal and Consumption of Water by Thermoelectric Power Plants in the United States, 2010}

By Timothy H. Diehl and Melissa A. Harris

A product of the USGS National Water Census and the USGS National Streamflow Information Program

Scientific Investigations Report 2014-5184 


\title{
U.S. Department of the Interior SALLY JEWELL, Secretary
}

\section{U.S. Geological Survey Suzette M. Kimball, Acting Director}

\author{
U.S. Geological Survey, Reston, Virginia: 2014
}

For more information on the USGS - the Federal source for science about the Earth, its natural and living resources, natural hazards, and the environment, visit http://www.usgs.gov or call 1-888-ASK-USGS.

For an overview of USGS information products, including maps, imagery, and publications, visit http://www.usgs.gov/pubprod

To order this and other USGS information products, visit http://store.usgs.gov

Any use of trade, firm, or product names is for descriptive purposes only and does not imply endorsement by the U.S. Government.

Although this information product, for the most part, is in the public domain, it also may contain copyrighted materials as noted in the text. Permission to reproduce copyrighted items must be secured from the copyright owner.

Suggested citation:

Diehl, T.H., and Harris, M.A., 2014, Withdrawal and consumption of water by thermoelectric power plants in the United States, 2010: U.S. Geological Survey Scientific Investigations Report 2014-5184, 28 p., http://dx.doi. org/10.3133/sir20145184.

ISBN 978-1-4113-3851-7

ISSN 2328-0328 (online) ISSN 2328-031X (print) 


\section{Contents}

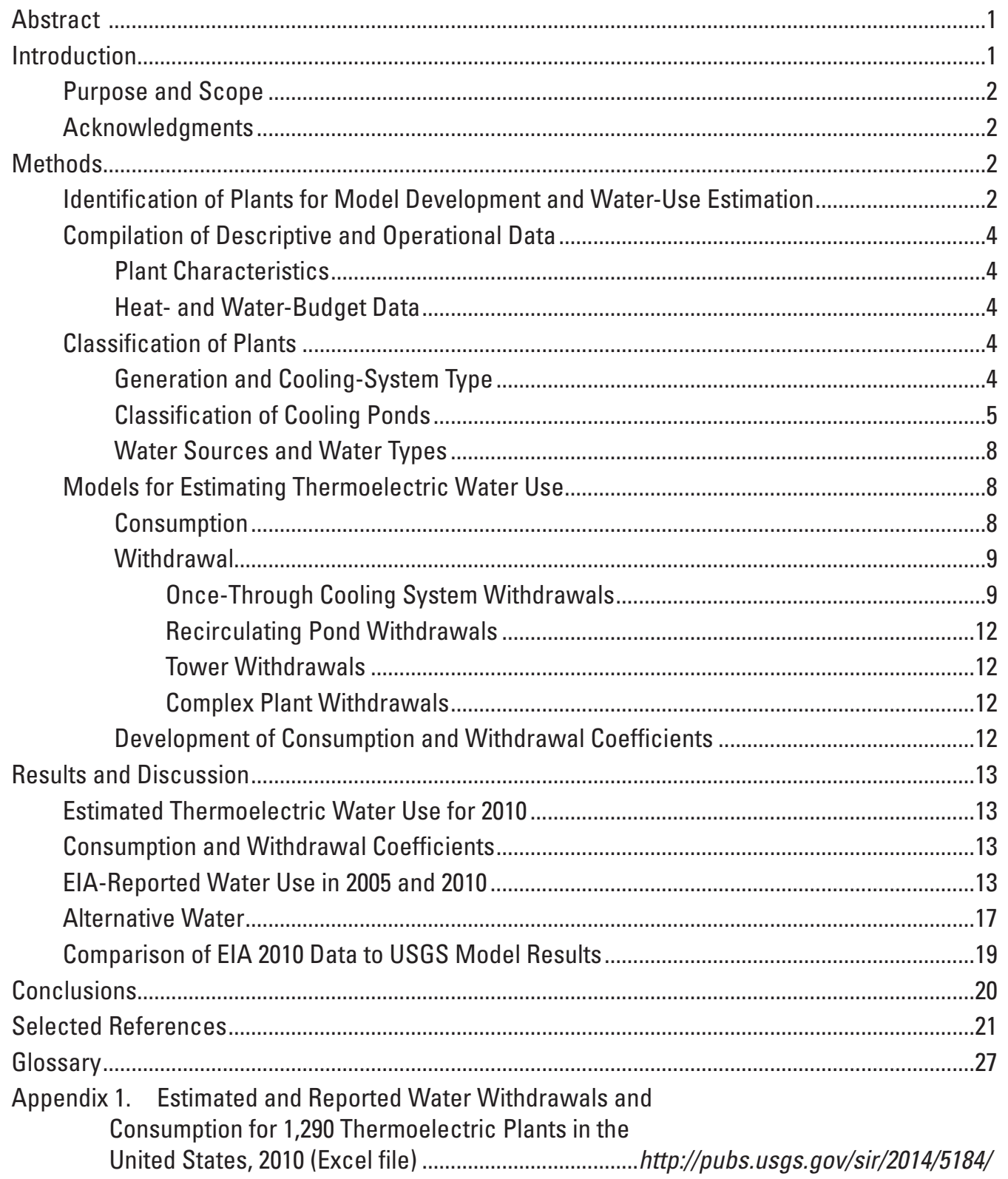




\section{Figures}

1. Map showing geographic distribution of the 1,290 thermoelectric power plants modeled to estimate water withdrawal and consumption in the United States, 2010.....3

2-7. Graphs showing-

2. Classifications of 32 plants at 28 once-through or recirculating cooling ponds for which water budgets were developed, including the watershed runoff threshold determining pond cooling category, for thermoelectric power plants in the United States

3. Selected reported condenser ranges and corresponding intake water temperatures for 128 thermoelectric power plants in the United States 10

4. Median, minimum, and maximum estimated condenser ranges and reported condenser ranges for thermoelectric power plants in the United States..... .11

5. Water withdrawal by generation type and cooling-system type for simple thermoelectric power plants, 2005 and 2010.

6. Net electrical generation by generation type and cooling-system type for simple thermoelectric power plants, 2005 and 2010 16

7. Water consumption by generation type and cooling-system type for simple thermoelectric power plants, 2005 and 2010.

8. Pie charts showing alternative water withdrawals by thermoelectric plants in the United States as reported to the U.S. Department of Energy, Energy Information Administration, and estimated by the U.S. Geological Survey, 2010

9. Pie charts showing alternative water consumption by thermoelectric plants in the United States as reported to the U.S. Department of Energy, Energy Information Administration, and estimated by the U.S. Geological Survey, 2010

\section{Tables}

1. Classification for condenser duty estimation method by generation type for thermoelectric plants in the United States.

2. Classification for modeling approach to consumption and withdrawal by cooling-system type for thermoelectric plants in the United States

3. Net electrical generation for water-using thermoelectric plants according to generation type and cooling-system type as reported to the U.S. Department of Energy, Energy Information Administration for 685 plants for 2005, 835 plants for 2010, and 1,290 plants for 2010 as analyzed by the U.S. Geological Survey .

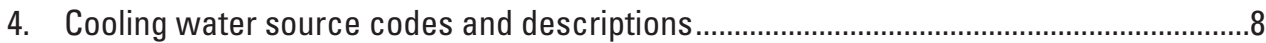

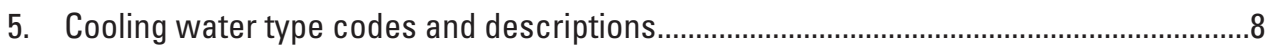

6. Thermoelectric plant water withdrawals by generation and cooling-system types as reported to the U.S. Department of Energy, Energy Information Administration for 2005 and 2010, and as modeled by the U.S. Geological Survey for 2010.

7. Thermoelectric plant water consumption by generation and cooling-system types as reported to the U.S. Department of Energy, Energy Information Administration for 2005 and 2010, and as modeled by the U.S. Geological Survey for 2010 .

8. Thermoelectric water-withdrawal coefficients calculated from flow rates and net electrical generation as reported to the U.S. Department of Energy, Energy Information Administration and as calculated from modeled estimates by the U.S. Geological Survey for 2010

9. Thermoelectric water-consumption coefficients calculated from flow rates and net electrical generation as reported to the U.S. Department of Energy, Energy Information Administration and as calculated from modeled estimates by the U.S. Geological Survey for 2010. 


\section{Conversion Factors and Datum}

\begin{tabular}{|c|c|c|}
\hline Multiply & By & To obtain \\
\hline \multicolumn{3}{|c|}{ Length } \\
\hline inch (in.) & 2.54 & centimeter $(\mathrm{cm})$ \\
\hline inch (in.) & 25.4 & millimeter $(\mathrm{mm})$ \\
\hline mile (mi) & 1.609 & kilometer $(\mathrm{km})$ \\
\hline \multicolumn{3}{|c|}{ Volume } \\
\hline gallon (gal) & 3.785 & liter (L) \\
\hline gallon (gal) & 0.1337 & cubic foot $\left(\mathrm{ft}^{3}\right)$ \\
\hline cubic foot $\left(\mathrm{ft}^{3}\right)$ & 0.02832 & cubic meter $\left(\mathrm{m}^{3}\right)$ \\
\hline \multicolumn{3}{|c|}{ Concentration } \\
\hline milligrams per liter $(\mathrm{mg} / \mathrm{L})$ & 0.058418 & grains per gallon (gr/gal) (U.S.) \\
\hline \multicolumn{3}{|c|}{ Pressure } \\
\hline atmosphere (atm) & 101.3 & kilopascal $(\mathrm{kPa})$ \\
\hline \multicolumn{3}{|c|}{ Energy } \\
\hline British thermal unit (Btu) & $1,055.06$ & joule $(\mathrm{J})$ \\
\hline British thermal unit (Btu) & 252.16 & calorie (cal) \\
\hline British thermal unit (Btu) & 0.0002931 & kilowatt hour $(\mathrm{kWh})$ \\
\hline gigawatt hour (GWh) & $3.412 \times 10^{9}$ & British thermal unit (Btu) \\
\hline kilowatt hour (kWh) & $3.6 \times 10^{6}$ & joule $(\mathrm{J})$ \\
\hline kilowatt hour (kWh) & 3,412 & British thermal unit (Btu) \\
\hline megawatt (MW) & $1 \times 10^{6}$ & joule per second $(\mathrm{J} / \mathrm{s})$ \\
\hline megawatt (MW) & $8.6042 \times 10^{8}$ & calories per hour (cal/h) \\
\hline megawatt hour (MWh) & $3.6 \times 10^{9}$ & joule $(\mathrm{J})$ \\
\hline megawatt hour (MWh) & $3.412 \times 10^{6}$ & British thermal unit (Btu) \\
\hline \multicolumn{3}{|c|}{ Rate } \\
\hline gallon per kilowatt hour (gal/kWh) & $1.0515 \times 10^{-6}$ & liter per joule $(\mathrm{L} / \mathrm{J})$ \\
\hline gallon per kilowatt hour (gal/kWh) & $4.3995 \times 10^{-6}$ & liter per calorie (L/cal) \\
\hline gallon per megawatt hour (gal/MWh) & $1.0515 \times 10^{-9}$ & liter per joule $(\mathrm{L} / \mathrm{J})$ \\
\hline gallon per megawatt hour (gal/MWh) & $4.3995 \times 10^{-9}$ & liter per calorie $(\mathrm{L} / \mathrm{cal})$ \\
\hline $\begin{array}{l}\text { gallon per million British thermal units } \\
\text { (gal/MMBtu) }\end{array}$ & 3.412 & gallon per megawatt hour (gal/MWh) \\
\hline $\begin{array}{l}\text { gallon per million British thermal units } \\
\text { (gal/MMBtu) }\end{array}$ & $3.5879 \times 10^{9}$ & liter per joule $(\mathrm{L} / \mathrm{J})$ \\
\hline billion gallons per day $(\mathrm{Bgal} / \mathrm{d})$ & 43.813 & cubic meter per second $\left(\mathrm{m}^{3} / \mathrm{s}\right)$ \\
\hline million gallons per day $(\mathrm{Mgal} / \mathrm{d})$ & $4.3813 \times 10^{-2}$ & cubic meter per second $\left(\mathrm{m}^{3} / \mathrm{s}\right)$ \\
\hline
\end{tabular}

Temperature in degrees Fahrenheit $\left({ }^{\circ} \mathrm{F}\right)$ may be converted to degrees Celsius $\left({ }^{\circ} \mathrm{C}\right)$ as follows:

${ }^{\circ} \mathrm{C}=\left({ }^{\circ} \mathrm{F}-32\right) / 1.8$

Horizontal coordinate information is referenced to the North American Datum of 1983 (NAD 83).

Concentrations of chemical constituents in water are given in milligrams per liter (mg/L). 


\section{Selected Acronyms and Abbreviations}

$\begin{array}{ll}\text { EIA } & \text { U.S. Department of Energy, Energy Information Administration } \\ \text { EPA } & \text { U.S. Environmental Protection Agency } \\ \text { FAO } & \text { Food and Agriculture Organization } \\ \text { FGD } & \text { flue-gas desulfurization } \\ \text { GAO } & \text { U.S. Government Accountability Office } \\ \text { GWh } & \text { gigawatt hour } \\ \text { MMBtu } & \text { million British thermal units } \\ \text { NCDC } & \text { National Climatic Data Center } \\ \text { NETL } & \text { National Energy Technology Laboratory } \\ \text { NGCC } & \text { natural gas combined cycle } \\ \text { NOAA } & \text { National Oceanic and Atmospheric Administration } \\ \text { OCLCD } & \text { Quality Controlled Local Climatological Data } \\ \text { SSURGO } & \text { Soils Survey Geographic (database) } \\ \text { USGS } & \text { U.S. Geological Survey }\end{array}$




\title{
Withdrawal and Consumption of Water by Thermoelectric Power Plants in the United States, 2010
}

\author{
By Timothy H. Diehl and Melissa A. Harris
}

\section{Abstract}

Estimates of water use at thermoelectric plants were developed by the U.S. Geological Survey based on linked heat and water budgets, and complement reported thermoelectric water withdrawals and consumption. The heat- and water-budget models produced withdrawal and consumption estimates, including thermodynamically plausible ranges of minimum and maximum withdrawal and consumption, for 1,290 water-using plants in the United States for 2010. Total estimated withdrawal for 2010 was about 129 billion gallons per day (Bgal/d), and total estimated consumption was about 3.5 Bgal/d. In contrast, total withdrawal reported by the U.S. Department of Energy, Energy Information Administration (EIA), was about 24 percent higher than the modeled estimates, and total EIA-reported consumption was about 8 percent lower. Most thermoelectric generation in 2010 was not associated with thermodynamically plausible EIA-reported values of both withdrawal and consumption.

An analysis of 2005 and 2010 EIA-reported water use indicated that withdrawal and consumption declined 18 percent and 34 percent, respectively. Alternative water types (types other than freshwater) accounted for approximately 25 percent of all withdrawals in 2010, most of which occurred at plants with once-through cooling systems using saline and brackish tidal waters. Differences among withdrawal and consumption coefficients based on EIA-reported water use for 2005 and 2010 and heat-budget model results for 2010 reveal opportunities for improving consistency and accuracy of reporting of water-use information at the plant scale.

\section{Introduction}

Water withdrawal and consumption at thermoelectric power plants represent an important but poorly quantified component of water use in the United States. Thermoelectric water withdrawals in 2005 were estimated at about 200 billion gallons per day $(\mathrm{Bgal} / \mathrm{d})$ and represented the largest single category of water withdrawals nationwide for that year (Kenny and others, 2009). In contrast, thermoelectric consumption was estimated to be only about 3 percent of national freshwater consumption in 1995 (Solley and others, 1998) and owing to uncertainties in reported information, the U.S. Geological
Survey (USGS) suspended publication of thermoelectric consumption in its 2000 and 2005 water-use compilations (Hutson and others, 2004; Kenny and others, 2009). Uncertainties in estimates of thermoelectric water withdrawal ${ }^{1}$ and consumption reflect numerous factors, including contradictory definitions among different organizations, inconsistency in applying definitions, and data-quality problems and incompleteness in key databases (Diehl, 2011; Diehl and others, 2013). While published coefficients associating water consumption with power generation might be used to estimate national water consumption by thermoelectric power plants, available coefficients vary widely (Macknick and others, 2011) and fail to provide additional certainty in estimates. Given these difficulties, the National Research Council (2002) supported the USGS decision to suspend publication while noting a national interest in addressing the "financial and institutional pressures" that drove it.

As the Nation's demand for water and energy continue to increase, there is growing awareness of the need for reliable estimates of withdrawal and consumption of water at thermoelectric plants (Murkowski, 2014). This awareness was expressed in a report by the U.S. Government Accountability Office (GAO) (2009), which recommended that the USGS resume reporting consumptive water use by thermoelectric power generation in the United States. In addition, the GAO (2009) report emphasized the need to begin tracking thermoelectric use of alternative water sources such as treated wastewater.

In 2010, the USGS responded to the GAO recommendation by initiating a program to improve the accuracy and precision of thermoelectric water withdrawal and consumption information. As part of this effort, Diehl and others (2013) developed a method to constrain and validate waterconsumption estimates by comparing them to linked heat and water budgets based on fuel use and electrical generation, which generally are tracked at power plants. Based on this information, the difference between reported energy input and output from each plant provides an approximation of the total energy available to consume water by evaporation. When further adjusted for the particular performance of each plant's cooling and electrical generation system, the result is a reasonable constraint on what is physically possible in terms of water consumption at each plant.

\footnotetext{
${ }^{1}$ Words and phrases shown in bold are listed in the Glossary.
} 
Diehl and others (2013) describe the rationale and computational details for the application of linked heat- and waterbudget models to estimate water consumption at thermoelectric power plants of various configurations based on generator, boiler, and cooling-system type. They did not include estimates of consumption, nor did they address water withdrawal, which may be in principle constrained by similar thermodynamic assumptions. Water-use withdrawals are reported by the USGS as a removal from a natural source. Some power plants recirculate water from small ponds that are periodically replenished from other sources. Other plants draw water from ponds of similar size that receive sufficient runoff from their watersheds to eliminate the need for artificial replenishment; such ponds typically discharge to other bodies of water. Because the size of a pond does not determine its relation to the natural hydrologic system, distinguishing once-through withdrawals from recirculated pumpage requires a more complex analysis that has not been addressed in earlier work.

\section{Purpose and Scope}

This report builds on the work reported by Diehl and others (2013) by presenting: (1) an extension of earlier thermodynamic analysis to include withdrawal; (2) a method for distinguishing once-through from recirculating surface-water cooling systems; (3) a reclassification of 1,290 power plants by electrical generation type, cooling-system type, water type, and water source, including use of water from alternative sources; (4) application and in some cases modification of published heat- and water-budget models and estimates of thermoelectric water consumption at all 1,290 power plants distributed across the United States; and (5) application of thermodynamically constrained models of water withdrawals at the same plants.

The models described in this report estimate water consumption and withdrawal at the plant scale. Plant-scale estimates are summed to produce national totals that are compared to other available estimates. Coefficients of consumption and withdrawal were developed for various classes of power plants and compared to other published coefficients. It is important to note that the primary purpose of this report is not to provide national estimates of water consumption and withdrawal but rather to improve estimation at the scale of the individual power plant with the ultimate goal of better characterizing the role of thermoelectric water use in the national water budget. Consequently the estimates provided here may not agree with other published information at the national scale. The analyses presented in this report directly support several strategic science goals of the USGS, notably improving understanding of (1) interactions between the engineered and natural components of the hydrologic cycle, (2) the national water budget, and (3) effects of energy production on natural resources (Evenson and others, 2013; Ferrero and others, 2013).

\section{Acknowledgments}

Many individuals within and outside of the USGS contributed to this report. Particular acknowledgement is due Susan S. Hutson, USGS (retired), for decades of devoted public service and collegial support and especially for her leadership in the analysis of thermoelectric water use by the USGS. Thanks are also due to technical and editorial reviewers and numerous colleagues who provided critical feedback on different sections of the report throughout its preparation. Members of the USGS National Water Use Leadership Team provided input and guidance on pond classification. This study was funded by the National Water Census and the National Streamflow Information Program of the USGS.

\section{Methods}

Thermoelectric plants that withdraw water were categorized based on their methods of generating electricity and disposing of waste heat. Their withdrawal of water and consumption of freshwater were estimated using heat- and water-budget models and data on fuel use and net generation reported to EIA.

\section{Identification of Plants for Model Development and Water-Use Estimation}

Diehl and others (2013) produced a list of 1,284 plants using plant-characteristic data from the 2010 EIA-860 Annual Electric Generator Report database (U.S. Department of Energy, Energy Information Administration, 2011a) to develop a heat-budget model for estimating consumption. That list included electric utilities and independent power producers operating generators and cooling systems using water. It did not include industrial or commercial facilities. Some plants previously included on that list were found on review to be unsuitable for water-use estimation, and others were added where additional data warranted. Initially only plants coded as operational were included on the list; however, 29 plants that were originally reported as non-operational were found to have produced electricity in 2010 and were added. Another 13 plants on the original list were discovered to have dry cooling systems and were removed. Nine geothermal plants powered by binary cycle turbines were excluded because heat- and water-budgets could not be constructed. Lastly, one concentrating solar thermal plant (Maricopa Solar in Arizona) does not use water for energy conversion and was removed. After these various corrections were made, a total of 1,290 thermoelectric, water-using power plants were carried forward for computation of water withdrawals and consumption (fig. 1; appendix 1). 


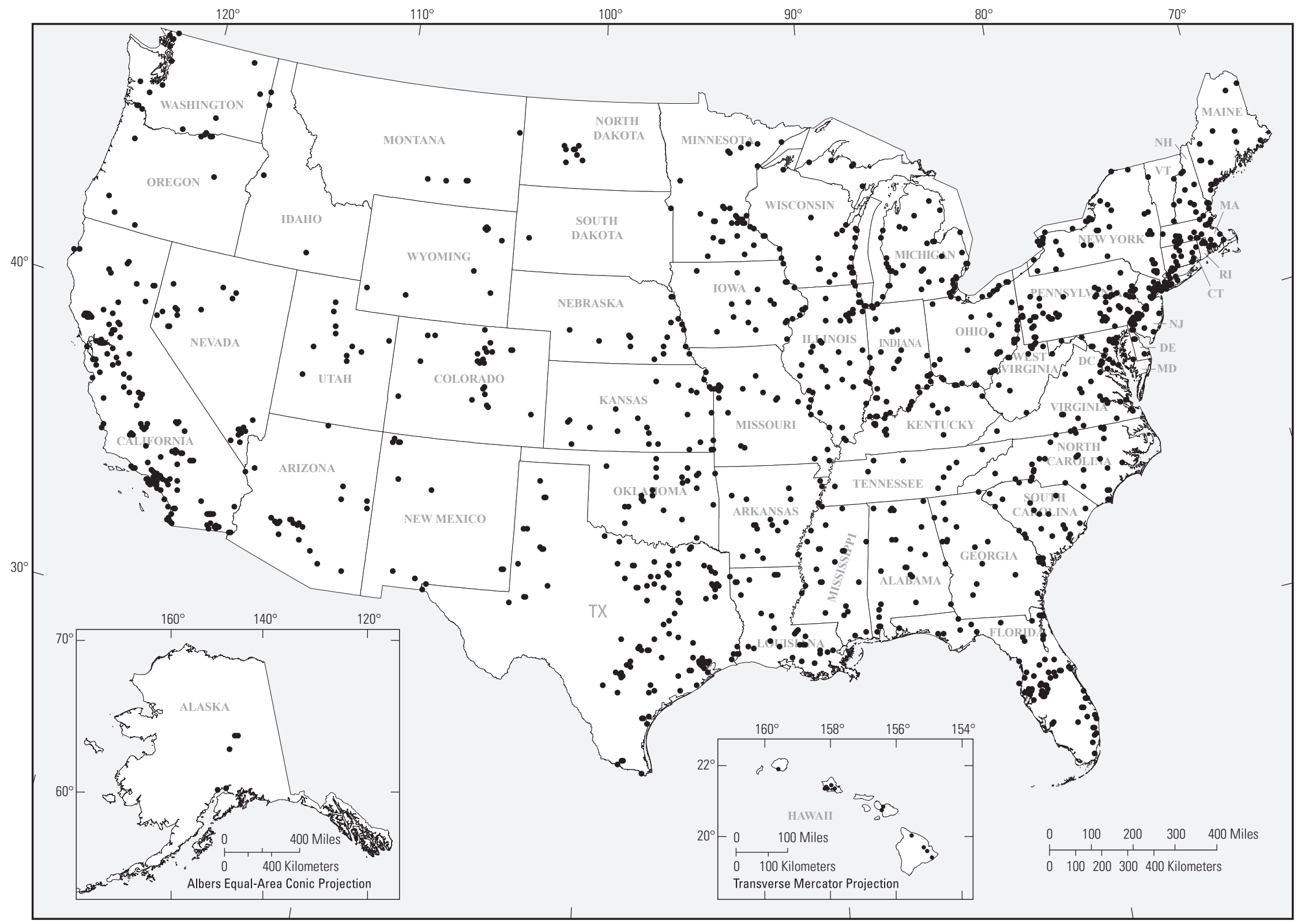

Base from U.S. Geological Survey, 1:2,000,000 Digital Line Data,

Albers Equal-Area Conic Projection, NAD 83

Figure 1. Geographic distribution of the 1,290 thermoelectric power plants modeled to estimate water withdrawal and consumption in the United States, 2010.

[Thermoelectric plants in Puerto Rico and the U.S. Virgin Islands are not surveyed by the U.S. Department of Energy, Energy Information Administration.] 


\section{Compilation of Descriptive and Operational Data}

Plant-specific operational, locational, environmental, and other characteristic data were compiled from various sources and used to classify plants for the estimation of consumption and withdrawal. These data were available in varying degrees of quality and completeness, and some had to be estimated.

\section{Plant Characteristics}

EIA-reported plant characteristic data were used to classify plants according to generation type and cooling type.

EIA-reported prime movers and energy sources for each plant were used to classify plants into one of five generation types. Data directly related to electrical generation were assumed to be accurate because information regarding fuel use and production are fundamental to the financial operation of power plants and therefore are routinely tracked for general business accounting.

Information regarding cooling-system types was not as consistent or complete. Power plants with water-using generation capacities less than 100 megawatts (MW) are not required to report cooling system information to EIA, and those that are required to do so sometimes provide inaccurate information. In recognition of this, cooling-system types were verified for all plants. Plant location data were obtained from EIA, U.S. Environmental Protection Agency (EPA), and National Energy Technology Laboratory (NETL) databases (U.S. Department of Energy, Energy Information Administration, 2001, 2009, 2011a; U.S. Department of Energy, National Energy Technology Laboratory, 2007b; U.S. Environmental Protection Agency, 2007a, n.d.), and verified and in some cases corrected (Diehl and others, 2013). Using the verified locations, recirculating cooling towers, once-through cooling system intake structures and discharge outlets were identified from aerial imagery as described by Diehl and others (2013). For many plants, the aerial-photo interpretation also allowed characterization of the surface-water source.

\section{Heat- and Water-Budget Data}

Plant-characteristic and operational data needed for linked heat and water budgets included net generation, fuel consumption, boiler efficiencies, and environmental data, notably air and water temperature (Diehl and others, 2013). These data varied widely in availability and quality among the different generation types. Among all generation-types, net generation data were of good quality. However, the quality of information on boiler efficiencies and the energy content of fuels varied and had to be estimated for some generation types (Diehl and others, 2013).

Most environmental data used in this analysis are published by the National Oceanic and Atmospheric Administration (NOAA). Only data from weather stations reporting 12 months of meteorological observations were used as model input variables. USGS and EIA water-temperature data were screened to eliminate extreme values and irregular seasonal patterns (Diehl and others, 2013).

\section{Classification of Plants}

Thermoelectric power plants were classified by coolingsystem type and generation type in order to select which heat- and water-budget model to apply to each plant and for comparison of model-estimated water use to EIA-reported data. The distinction between once-through and recirculating cooling ponds was defined based on the relation of runoff and pond depth. An additional classification of plants was developed based on water source and water type to support an analysis of the emergent use of alternative water sources.

\section{Generation and Cooling-System Type}

The share of fuel energy converted to waste heat in the condenser depends largely on generation technology and is reflected in the estimation method applied. Reported prime movers and energy sources were used to classify plants into one of five generation types (table 1). Common to all waterusing generation types are steam-driven turbines, which may be powered by a variety of heat sources such as fossil-fuel combustion, or nuclear, geothermal, or solar energy. Combined-cycle plants have both combustion and steam turbines, which at a few plants operate together to drive a single generator but typically operate separately.

Cooling-system type determined which modeling approaches were used (table 2). Cooling systems were broadly classified as wet recirculating cooling towers and surfacewater cooling systems. Surface-water cooling systems were

Table 1. Classification for condenser duty estimation method by generation type for thermoelectric plants in the United States.

\begin{tabular}{|c|c|c|c|}
\hline Generation type & Prime mover & Energy source & $\begin{array}{c}\text { Estimation } \\
\text { method }\end{array}$ \\
\hline $\begin{array}{l}\text { Combustion } \\
\text { steam }\end{array}$ & Steam & $\begin{array}{l}\text { Various, } \\
\text { dominated } \\
\text { by coal }\end{array}$ & \multirow{4}{*}{$\begin{array}{l}\text { Linked heat } \\
\text { and water } \\
\text { budgets with } \\
\text { appropriate } \\
\text { cooling type }\end{array}$} \\
\hline Combined cycle & $\begin{array}{l}\text { Combined cycle } \\
\text { combustion part } \\
\text { Combined cycle } \\
\text { steam part } \\
\text { Combined cycle } \\
\text { single shaft }\end{array}$ & $\begin{array}{c}\text { Various, } \\
\text { dominated by } \\
\text { natural gas }\end{array}$ & \\
\hline Nuclear & Steam & Nuclear & \\
\hline Geothermal & Steam & Geothermal & \\
\hline Solar steam & Steam & Solar & $\begin{array}{l}\text { Water- } \\
\text { consumption } \\
\text { coefficient }\end{array}$ \\
\hline
\end{tabular}


Table 2. Classification for modeling approach to consumption and withdrawal by cooling-system type for thermoelectric plants in the United States.

\begin{tabular}{ccc}
\hline $\begin{array}{c}\text { Cooling-system } \\
\text { type }\end{array}$ & $\begin{array}{c}\text { Consumption } \\
\text { modeling } \\
\text { approach }\end{array}$ & $\begin{array}{c}\text { Withdrawal } \\
\text { modeling } \\
\text { approach }\end{array}$ \\
\hline $\begin{array}{c}\text { Wet freshwater } \\
\text { recirculating } \\
\text { cooling tower }\end{array}$ & $\begin{array}{c}\text { Wet tower } \\
\text { evaporation } \\
\text { model }\end{array}$ & $\begin{array}{c}\text { Ratio to } \\
\text { consumption }\end{array}$ \\
$\begin{array}{c}\text { Recirculating } \\
\text { pond or canal }\end{array}$ & $\begin{array}{c}\text { Water surface } \\
\text { evaporation model and } \\
\text { Penman-Monteith model }\end{array}$ & $\begin{array}{c}\text { Equal to } \\
\text { consumption }\end{array}$ \\
$\begin{array}{c}\text { Once-through } \\
\text { freshwater }\end{array}$ & $\begin{array}{c}\text { Water surface } \\
\text { evaporation model }\end{array}$ & $\begin{array}{c}\text { Based on } \\
\text { condenser duty } \\
\text { and range }\end{array}$ \\
\hline $\begin{array}{c}\text { Once-through } \\
\text { saline water }\end{array}$ & Not modeled & $\begin{array}{c}\text { Based on } \\
\text { condenser duty } \\
\text { and range }\end{array}$ \\
\hline $\begin{array}{c}\text { Wet saline } \\
\text { recirculating } \\
\text { cooling tower }\end{array}$ & Not modeled & $\begin{array}{c}\text { Not modeled } \\
\text { Dry cooling } \\
\text { systems }\end{array}$ \\
\hline
\end{tabular}

further subdivided into once-through cooling systems and recirculating cooling ponds.

The 1,290 plants selected for this analysis represent 84 percent of total net generation reported to EIA in 2010 (U.S. Department of Energy, Energy Information Administration, 2011b; table 3). Of these, 892 are relatively straightforward in design and can be characterized as simple combinations of one generation type, one dominant fuel source (providing 90 percent or more of total fuel heat), and one cooling-system type. These "simple plants" ${ }^{2}$ account for about 77 percent of the 2010 net generation reported by the 1,290 plants in this analysis.

The computation of coefficients for consumption and withdrawal is fairly direct for simple plants. However, geothermal and solar thermal plants (Diehl and others, 2013) and plants that have multiple cooling-system types, generation technologies, and/or use multiple fuels present a number of challenges in allocating water use to distinct generation types and were not included in the evaluation of categorical coefficients. These "complex plants" represent about 23 percent of net generation for all plants considered in this analysis (table 3).

EIA-reported water-use data and net generation were analyzed for 2005 and 2010 to evaluate changes in withdrawal and consumption flow rates, electrical generation, and water-use coefficients by generation type and cooling type. To allow comparison of overall use in EIA data reported for 2005 and 2010, withdrawal and consumption was estimated for

\footnotetext{
${ }^{2}$ In this report, the phrase "simple plants" is used to refer to those with one dominant fuel type, a single type of generation technology, and a single cooling type. Other plants are termed "complex plants."
}

63 nuclear plants for 2005, a year when they were not required to report water use, and added to EIA water-use data for that year. These values were computed as the product of net generation and the USGS-computed coefficients of withdrawal and consumption, respectively. Three nuclear plants co-located with fossil-fuel powered generators did report water use, and those data were used in the analysis.

For comparison of reported data to model estimates, plants that reported water use to EIA were categorized by generation type and cooling-system type. Only water-using plants that have generating capacities of $100 \mathrm{MW}$ and greater are required to report water use to EIA (U.S. Department of Energy, Energy Information Administration, 2006a and 2011a). For 2010, 835 such plants represented 82 percent of total net generation (U.S. Department of Energy, Energy Information Administration, 2011b; table 3). Of these, 151 were identified as complex plants (table 3 ) and excluded from the evaluation of categorical coefficients. In 2005, only 685 waterusing plants reported to EIA, of which 147 were identified as complex plants (U.S. Department of Energy, Energy Information Administration, 2006a; table 3) and similarly excluded.

\section{Classification of Cooling Ponds}

In water-use reporting, the term "withdrawal" commonly refers to water diverted from a natural hydrologic source. Though this idea is relatively straightforward, withdrawal as defined here is not typically measured directly at power plants and often must be inferred from other available information, such as pumpage or flow through a condenser. At most plants volumes reported as withdrawal are flow through condensers in once-through cooling systems or makeup flows to recirculating cooling systems. Many plants reported apparently contradictory combinations of cooling-system type and withdrawal-flow through the condenser reported as withdrawal from recirculating ponds or makeup flow reported as withdrawal to once-through systems. Such contradictions in the reported data indicate a need for an independent approach to distinguish once-through from recirculating cooling ponds. This distinction can change water withdrawal at a plant by as much as two orders of magnitude.

Differentiating recirculating and once-through cooling ponds required dividing a continuum from isolated ponds without watersheds to ponds connected to the natural system through inflow and outflow. Typically, recirculating ponds are artificial and surrounded by levees, lack large watersheds, and receive little natural inflow aside from direct precipitation and diversions from natural hydrologic systems. Once-through ponds are typically larger reservoirs with sizable watersheds that supply sufficient runoff to maintain water levels and outflows during years of normal precipitation. Most cooling ponds can easily be classified as recirculating or once-through; however, many ponds have intermediate characteristics that make them harder to classify. Some ponds have small watersheds that provide substantial natural inflows, but not enough to obviate the need for makeup flows. Others have watersheds 
Table 3. Net electrical generation for water-using thermoelectric plants according to generation type and cooling-system type as reported to the U.S. Department of Energy, Energy Information Administration for 685 plants for 2005, 835 plants for 2010, and 1,290 plants for 2010 as analyzed by the U.S. Geological Survey (USGS).

[Values may not sum to totals because of independent rounding. All net electrical generation is in gigawatt hours; NGCC, natural gas combined cycle; NA, not applicable; NR, not reported; Complex, geothermal and solar thermal plants and plants that have multiple cooling-system types, generation technologies, and/or use multiple fuels]

\begin{tabular}{|c|c|c|c|c|c|c|c|c|c|c|c|c|c|c|c|c|c|c|}
\hline \multirow{4}{*}{$\begin{array}{l}\text { Genera- } \\
\text { tion } \\
\text { type }\end{array}$} & \multicolumn{15}{|c|}{ Cooling-system type } & \multirow{2}{*}{\multicolumn{3}{|c|}{ Totals }} \\
\hline & \multicolumn{3}{|c|}{ Once-through saline } & \multicolumn{3}{|c|}{ Once-through fresh } & \multicolumn{3}{|c|}{ Recirculating pond } & \multicolumn{3}{|c|}{ Recirculating tower } & \multicolumn{3}{|c|}{ Complex } & & & \\
\hline & \multicolumn{2}{|c|}{ EIA } & \multirow{2}{*}{$\begin{array}{c}\text { USGS } \\
2010\end{array}$} & \multicolumn{2}{|c|}{ EIA } & \multirow{2}{*}{$\begin{array}{c}\text { USGS } \\
2010\end{array}$} & \multicolumn{2}{|c|}{ EIA } & \multirow{2}{*}{$\begin{array}{c}\text { USGS } \\
2010\end{array}$} & \multicolumn{2}{|c|}{ EIA } & \multirow{2}{*}{$\begin{array}{c}\text { USGS } \\
2010\end{array}$} & \multicolumn{2}{|c|}{ EIA } & \multirow{2}{*}{$\begin{array}{c}\text { USGS } \\
2010\end{array}$} & \multicolumn{2}{|c|}{ EIA } & \multirow{2}{*}{$\begin{array}{c}\text { USGS } \\
2010\end{array}$} \\
\hline & 2005 & 2010 & & 2005 & 2010 & & 2005 & 2010 & & 2005 & 2010 & & 2005 & 2010 & & 2005 & 2010 & \\
\hline Oil & 23,721 & 4,892 & 5,091 & 5,126 & 72 & 137 & NR & NR & NA & 369 & 205 & 413 & NA & NA & NA & 29,216 & 5,169 & 5,641 \\
\hline Nuclear & 162,092 & 160,038 & 160,038 & 199,521 & 215,991 & 144,978 & 83,282 & 86,114 & 77,502 & 260,680 & 272,506 & 272,506 & NA & NA & NA & 705,575 & 734,649 & 655,023 \\
\hline NGCC & NR & 33,483 & 30,773 & 512 & 16,938 & 14,184 & 9,547 & 4,767 & 16,707 & 145,261 & 432,426 & 492,128 & NA & NA & NA & 155,320 & 545,133 & 553,791 \\
\hline Gas steam & 15,589 & 10,233 & 11,723 & 16,907 & 20,449 & 22,701 & 9,340 & 7,845 & 3,484 & 16,105 & 12,657 & 14,471 & NA & NA & NA & 57,940 & 51,184 & 52,378 \\
\hline Coal & 31,567 & 33,519 & 26,854 & 652,545 & 556,564 & 558,754 & 127,676 & 122,777 & 104,311 & 677,908 & 727,587 & 731,552 & NA & NA & NA & $1,489,695$ & $1,443,609$ & $1,421,471$ \\
\hline Complex & NA & NA & NA & NA & NA & NA & NA & NA & NA & NA & NA & NA & 691,082 & 610,374 & 781,815 & 691,082 & 610,374 & 781,815 \\
\hline Totals & 232,969 & 242,164 & 234,478 & 874,610 & 810,014 & 740,753 & 229,845 & 221,503 & 202,003 & $1,100,322$ & $1,445,380$ & $1,511,069$ & 691,082 & 610,374 & 781,815 & $3,128,829$ & $3,329,437$ & $3,470,119$ \\
\hline
\end{tabular}


large enough to maintain water levels in most years, but require makeup flows during droughts. Of the 92 thermoelectric plants located on cooling ponds in 2010, 36 were classified on examination as having recirculating ponds, and 24 as having oncethrough ponds.

Categorization of the remaining 32 plants required additional analysis. Simple water budgets were developed to evaluate natural and plant-induced influences on the 28 ponds providing cooling water to these 32 plants ( 3 ponds are shared by multiple plants). These water budgets included monthly inflows from direct precipitation and watershed runoff and outflows of natural evaporation and forced evaporation. Groundwater exchange, pumped inputs, blowdown from the pond, and water use for non-cooling purposes could not be estimated due to a lack of reported information; these flows were assumed to be small relative to the errors in the water budget and ignored for the purpose of defining the cooling type.

Long-term average precipitation data were obtained from the National Climatic Data Center's (NCDC) 1981-2010 Climate Normals (National Oceanic and Atmospheric Administration, National Climatic Data Center, 2012b). Average direct precipitation to each of the 28 ponds categorized by water budgets was determined by interpolation among nearby weather stations. Using a 100-mile search radius, the distances from each pond to the nearest three weather stations were determined and used to compute a distance-weighted mean of direct precipitation based on the inverse distance from the respective pond.

Watershed runoff for each pond was calculated by multiplying long-term average precipitation by a runoff curve number (Cronshey, 1986) for each watershed. Runoff curve numbers were estimated based on dominant land use determined from the National Land Cover Database (Fry and others, 2011) and dominant soil hydrologic group determined from the Soils Survey Geographic (SSURGO) database (Soil Survey Staff, Natural Resources Conservation Service, U.S. Department of Agriculture, 2013). The depth of runoff from the watershed was multiplied by the ratio of the pond area to the watershed area to estimate the depth added to the pond by runoff.

Long-term average natural evaporation for each pond was obtained by interpolation from maps of U.S. evaporation (Farnsworth and others, 1982). Forced evaporation was estimated using methods described by Diehl and others (2013).

Thirty-two plants on the 28 cooling ponds were initially classified as recirculating or once-through based on aerial photographs. Using the calculated inflows and outflows, the average depth added to the pond by runoff was plotted against long-term net precipitation (direct precipitation to the pond minus natural pond evaporation) (fig. 2). Plants in arid regions

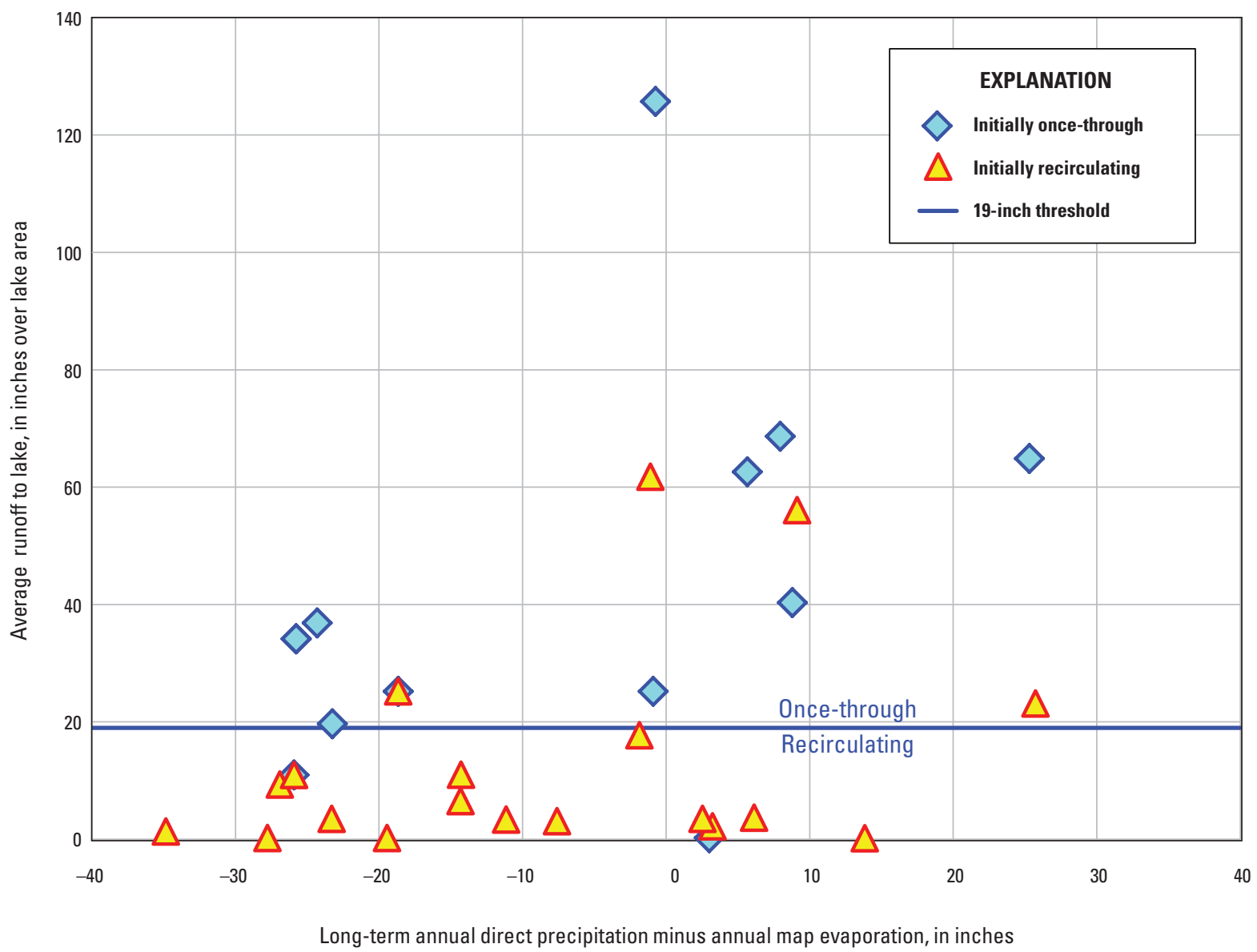

Figure 2. Classifications of 32 plants at 28 once-through or recirculating cooling ponds for which water budgets were developed, including the watershed runoff threshold determining pond cooling category, for thermoelectric power plants in the United States. [Initial classifications were determined by observation of aerial photographs.] 
plot to the left of plants in more humid regions; both recirculating and once-through plants are scattered along this climatic axis, suggesting that cooling-pond types are independent of climate. A value of 19 inches of depth added to the pond by runoff from the watershed was selected as the best threshold separating recirculating from once-through cooling systems. Four cooling systems initially classified as recirculating plotted above the 19-inch threshold and were reclassified as once-through, and two once-though systems were reclassified as recirculating.

\section{Water Sources and Water Types}

Plants reporting water use to the EIA include information about water sources (table 4) and types (table 5) and the names of the water sources from which they withdraw cooling water (U.S. Department of Energy, Energy Information Administration, 2011a). The names of water sources ranged from the specific water body name, to general descriptions such as "wells," "river," and "municipality." Alternative water types include reclaimed wastewater such as treated effluent from sewage-treatment plants and water not suitable for drinking or irrigation because of high concentrations of dissolved solids (brackish and saline water).

Two methods were used to identify plants using alternative water. First, 172 such plants were identified directly from EIA-reported water source and type (U.S. Department of Energy, Energy Information Administration, 2011a). Second, water sources and types for 12 plants were added based on plant locations and named water sources producing an alternate list of 184 plants. To conform to USGS definitions, 48 plants

Table 4. Cooling water source codes and descriptions.

[U.S. Department of Energy, Energy Information Administration, 2011a]

\begin{tabular}{cl}
\hline Code & \multicolumn{1}{c}{ Type of water source } \\
\hline SW & Surface water (example: river, canal, bay) \\
GW & $\begin{array}{c}\text { Groundwater (example: well, aquifer) } \\
\text { PD }\end{array}$ \\
$\begin{array}{c}\text { Plant discharge water (example: wastewater treatment } \\
\text { discharge) }\end{array}$ \\
OT & Other \\
\hline
\end{tabular}

Table 5. Cooling water type codes and descriptions.

[U.S. Department of Energy, Energy Information Administration, 2011a]

\begin{tabular}{cl}
\hline Code & \multicolumn{1}{c}{ Type of water } \\
\hline BR & Brackish water \\
FR & Freshwater \\
BE & Reclaimed wastewater \\
SA & Saline water \\
OT & Other \\
\hline
\end{tabular}

that reported brackish water to EIA were reclassified as saline plants. Also, seven plants that reported more than one water type code to EIA (for example, BR and BE) were moved to single water-type categories for the model estimates. Two plants that reported "other" water source and water type codes were modeled as surface-water saline plants. For the first list of 172 plants, EIA-reported withdrawal and consumption were used to calculate national totals of alternative water use by type. For the second list of 184 plants, alternative water withdrawal and consumption were estimated based on methods described in the following sections of this report and in Diehl and others (2013).

\section{Models for Estimating Thermoelectric Water Use}

Consumption was estimated using models developed by Diehl and others (2013) except for plants with recirculating cooling ponds, for which a new method was developed. Separate methods for estimating withdrawal were developed for once-through cooling systems, recirculating cooling ponds, and recirculating cooling towers. Coefficients of withdrawal and consumption weighted by net generation were calculated for categories of simple plants as outlined above.

\section{Consumption}

Water consumption at most plants was modeled by constructing heat and water budgets of the major energy flows into and out of thermoelectric power plants based on generation type and cooling-system type (Diehl and others, 2013). Two exceptions were solar thermal plants and plants with recirculating cooling ponds. For solar plants, consumption coefficients were used because reported plant data were insufficient to construct heat budgets (Diehl and others, 2013). Heat and water budgets constructed for recirculating cooling ponds included natural evaporation from the pond surface in addition to forced evaporation.

For plants with recirculating cooling ponds, natural evaporation was estimated monthly for 2010 by using the Food and Agriculture Organization's (FAO) version of the PenmanMonteith method (Allen and others, 1998). Input data for the Penman-Monteith model included meteorological and climatic data obtained from NCDC's Quality Controlled Local Climatological Data (QCLCD) database (National Oceanic and Atmospheric Administration, National Climatic Data Center, n.d.), and solar radiation data, obtained from NCDC's National Solar Radiation Database (National Oceanic and Atmospheric Administration, National Climatic Data Center, 2012a). The model was modified to use a reference-crop albedo of 0.05 to represent a water-body surface rather than land covered in vegetation (Allen and others, 1998). Monthly evaporation outputs from the Penman-Monteith model were adjusted by using interpolated averages of long-term evaporation acquired from U.S. evaporation atlases (Farnsworth and others, 1982). The mapped values are based on measured pan evaporation and provide an empirical constraint on the long-term model estimates. Adjusted monthly evaporation values were summed to obtain annual natural evaporation for each cooling pond. 


\section{Withdrawal}

Models of thermoelectric water withdrawal were developed for each plant's generation and cooling-system type based on plant-specific design parameters and operational data (tables 1 and 2). Withdrawal models apply principles of conservation of energy and mass first to estimate waste heat (condenser duty) and then to estimate withdrawal needed for cooling through evaporation, convection, and radiation, given system properties. Principal cooling-system types include once-through cooling systems, evaporative cooling towers, and recirculating cooling ponds. Water consumed in flue-gas desulfurization (FGD) and other in-plant processes, such as ash handling, inlet cooling, and boiler makeup, is relatively small compared to cooling requirements and may be drawn from cooling-system discharge flows, and so was not included in the estimate.

\section{Once-Through Cooling System Withdrawals}

Withdrawal from once-through cooling systems was modeled based on the thermal properties of water. Simply put, for a given quantity of heat energy imparted to water, the increase in temperature of that water is inversely proportional to its mass. For once-through thermoelectric cooling systems, this relation provides a means to quantify withdrawal (mass of water flowing through the condenser) as a function of condenser duty (heat transferred to the cooling water in the condenser) and condenser range (temperature difference between condenser inflow and outflow):

$$
W_{m}=\left(\frac{C D}{C R}\right) \div c_{p w},
$$

where

$$
\begin{array}{ll}
W_{m} & \text { is mass of water withdrawn, } \\
C R & \text { is condenser range in degrees of temperature, } \\
C D & \text { is condenser duty in heat, and } \\
c_{p w} & \text { is the specific heat capacity of water at } \\
& 1 \text { atmosphere pressure. }
\end{array}
$$

Volumetric water withdrawal was modeled by first solving for mass withdrawal using equation 1 and then converting water mass to volume based on the temperature of the withdrawn water when it entered the condenser:

$$
W_{v}=W_{m} \div \rho_{w T},
$$

where

$$
\begin{array}{ll}
W_{v} & \text { is volumetric water withdrawal, } \\
W_{m} & \text { is mass water withdrawal (eq. 1), and } \\
\rho_{w T} & \text { is the density of water at the temperature at } \\
& \text { which it enters the condenser. }
\end{array}
$$

If both condenser duty and condenser range are known, withdrawal by once-through cooling systems can be tightly constrained. Thus, much of the effort in computing oncethrough withdrawal estimates involved refinement of these two terms. Condenser duty was computed for each plant following the methods described by Diehl and others (2013). Condenser range was estimated based on the difference between reported withdrawal and discharge water temperatures at selected plants with once-through cooling; this difference was treated as "reported condenser range" at the selected plants. Because condenser range is closely related to the size of the condenser, it is essentially a fixed property for each plant operating at full power. At less than full power, operational flexibility increases somewhat, with the option of reducing condenser range by maintaining the design flow with a reduced waste-heat load. Decreasing the range in this way reduces steam pressure downstream from the turbine, potentially providing a small improvement in plant efficiency.

If the withdrawal and discharge water temperatures reported by the plant operator are close to the actual temperatures of cooling water entering and leaving the condenser, withdrawal can be accurately estimated based on modeled condenser duty. However, the wide variation in reported condenser ranges calls such accuracy into question. Thermoelectric power plants typically use medium-range condensers with design ranges of 10 to 25 degrees Fahrenheit $\left({ }^{\circ} \mathrm{F}\right)$ (Cheremisinoff and Cheremisinoff, 1981, p. 107; Stultz and Kitto, 1992, p. 57-11) which correspond to withdrawals from 12,000 to 4,800 gallons per million British thermal units (gal/MMBtu), respectively. For a typical combustion-steam plant having a 33-percent thermal efficiency, 88-percent boiler efficiency, and 2-percent auxiliary losses (Diehl and others, 2013), this would produce coefficients ranging from 66,000 to 26,000 gallons per megawatt hour (gal/MWh).

The overall distribution of reported condenser range relative to intake temperature is highly variable, including values apparently outside the typical design condenser range of $10-25^{\circ} \mathrm{F}$. About 4 percent of reported condenser ranges are below the product of $10^{\circ} \mathrm{F}$ and monthly plant capacity factor, thus implying that the condenser's design range is less than $10^{\circ} \mathrm{F}$. One plant reported a difference between intake water temperature and discharge water temperature of only $1^{\circ} \mathrm{F}$, at a capacity factor of 50 percent, suggesting a design condenser range of only $2{ }^{\circ} \mathrm{F}$. These low reported ranges may also reflect issues with estimated capacity factors involving inaccurate reported capacity or net generation.

Fifteen percent of reported ranges are greater than $25^{\circ} \mathrm{F}$, and 1 percent are greater than $40^{\circ} \mathrm{F}$. High-range condensers are feasible with a cold enough once-through water source, and their use in that context would be an economic choice at the time of plant design, saving on initial cost at the expense of slightly lower thermal efficiency. Very high reported condenser ranges (above $40^{\circ} \mathrm{F}$ ) may reflect reporting practices inconsistent with the assumption that the difference between intake- and discharge-water temperatures equals actual condenser range.

Predictions of condenser range were based on a relation developed for a subset of once-through cooling systems (U.S. Department of Energy, Energy Information Administration, 2011b) where reported temperatures and withdrawals reflect 
relatively reliable data-collection methods. Reported withdrawal rates were used where they were

1. Measured using an instantaneous flowmeter and pump running time,

2. Measured using a streamflow gage or weir,

3. Measured using a cumulative or continuous flowmeter, or

4. Estimated based on stated pump capacity and pump running time.

Reported intake and discharge temperatures were used where measured continuously or at regular intervals with a thermometer. Systems that used chlorine were not included because chlorine use is typical of recirculating systems, in which discharge temperature minus intake temperature is not generally equal to condenser range. Selected data meeting these criteria included 1,533 paired observations of monthly withdrawal and condenser range for 206 cooling systems at 128 plants (fig. 3). The number of data pairs per month ranged from 104 to 159 . Reported intake temperatures ranged from 28 to $97^{\circ} \mathrm{F}$, with 15 values of $32^{\circ} \mathrm{F}$ and 3 values less than $32^{\circ} \mathrm{F}$. The minimum reported condenser range was $1^{\circ} \mathrm{F}$, and the maximum was $47^{\circ} \mathrm{F}$; these ranges correspond to withdrawals of about 120,000 and 2,600 gal/MMBtu, respectively, and for a typical combustion-steam plant about 660,000 and $14,000 \mathrm{gal} / \mathrm{MWh}$, respectively. Low ranges are more common in cooling systems that did not receive condenser duty greater than 1,000 MMBtu per month.

To solve for monthly withdrawal using equation 1 , linear functions were derived to produce a "best estimate" of condenser range for each plant as a function of monthly average intake temperature and to establish thermodynamically plausible upper and lower bounds for condenser ranges. A number of approaches could have been used for this task, including simple linear regression with confidence limits (Helsel and Hirsch, 2002) and quantile regression (Cade and Noon, 2003). The approach used here was selected to preserve the observed distributions of condenser-range values across the range of intake temperature. To do this, the 1st, 50th, and 99th percentiles of condenser range were determined for data grouped in 5-degree intervals of monthly intake temperature, and linear functions were regressed through these percentiles (fig. 4). The resulting equations are

upper threshold: $C R_{U}=-0.2514 T_{i}+49.678^{\circ} \mathrm{F}$,

best estimate: $C R=-0.1044 T_{i}+22.464{ }^{\circ} \mathrm{F}$, and

lower threshold: $C R_{L}=-0.0093 T_{i}+2.9419^{\circ} \mathrm{F}$.

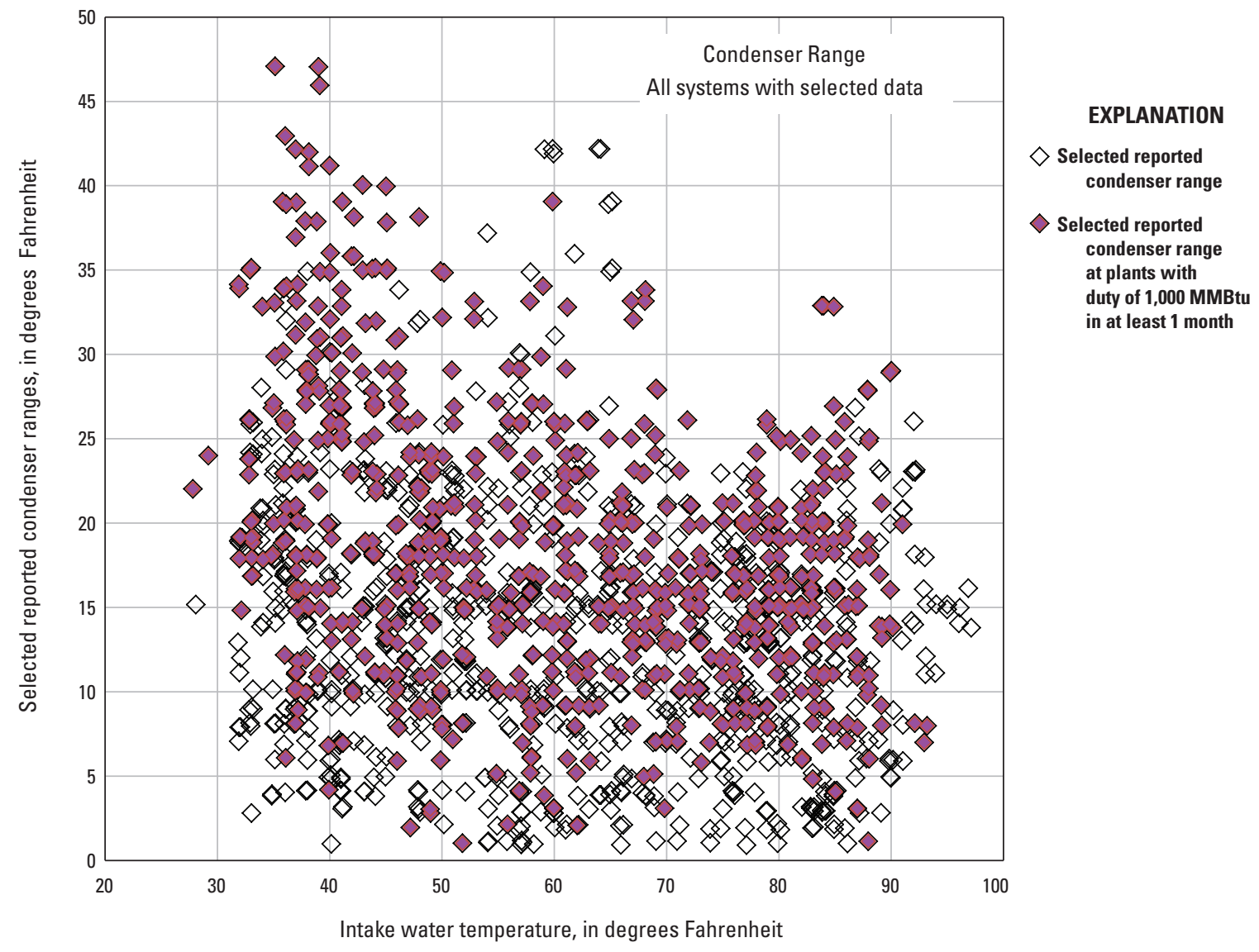

Figure 3. Selected reported condenser ranges and corresponding intake water temperatures for 128 thermoelectric power plants in the United States. [Data from the U.S. Department of Energy, Energy Information Administration] 
Over the entire range of intake water temperature, about 2.8 percent of reported condenser ranges were below the lower linear threshold, and 2.2 percent were above the upper linear threshold. These outlying values may result from errors in measurement or reporting, but might also reflect a mismatch between the actual cooling system and the simple model of once-through cooling systems used in this study.

Diehl and others (2013) noted that estimation error for condenser duty may be as high as 15 percent or greater. To account for such error and other factors in estimating withdrawal, a margin of 18 percent was added to the maximum withdrawal estimates and subtracted from minimum estimates. These adjustments to the upper and lower thresholds expanded the predicted limits to include 98.5 percent of selected reported withdrawals. This approach conservatively assumes that errors in condenser range and duty are correlated in such a way as to be multiplicative in estimated withdrawal; they are more likely independent or nearly so. These limiting thresholds for thermodynamically plausible withdrawal are far enough apart to include nearly all once-through cooling systems that fit the analytical framework of this study. The upper condenser range threshold is about twice the best estimate, and the lower threshold is about one-sixth of the best estimate. Estimates outside these thresholds probably represent differences in defining withdrawal or errors in reporting.

Systematic differences between estimates and EIAreported withdrawals cannot be attributed to the assumption that withdrawal is inversely proportional to estimated condenser range. Although estimated and reported withdrawals vary widely at individual plants, a comparison of aggregate totals for the selected plants used to develop the condenser-range estimator shows the model to be unbiased. The degree of bias in estimates was evaluated based on the reported withdrawals associated with the selected ranges used to develop the median-range estimator. An apparent monthly condenser duty was derived for each cooling system as the product of reported withdrawal and condenser range. Dividing this reported condenser duty by an estimated condenser range from the median linear function yielded a corresponding estimated withdrawal. Comparing the total of all monthly reported withdrawals (1,459 billion cubic feet) to estimated (1,461 billion cubic feet) withdrawals for the same systems shows a startling degree of similarity.

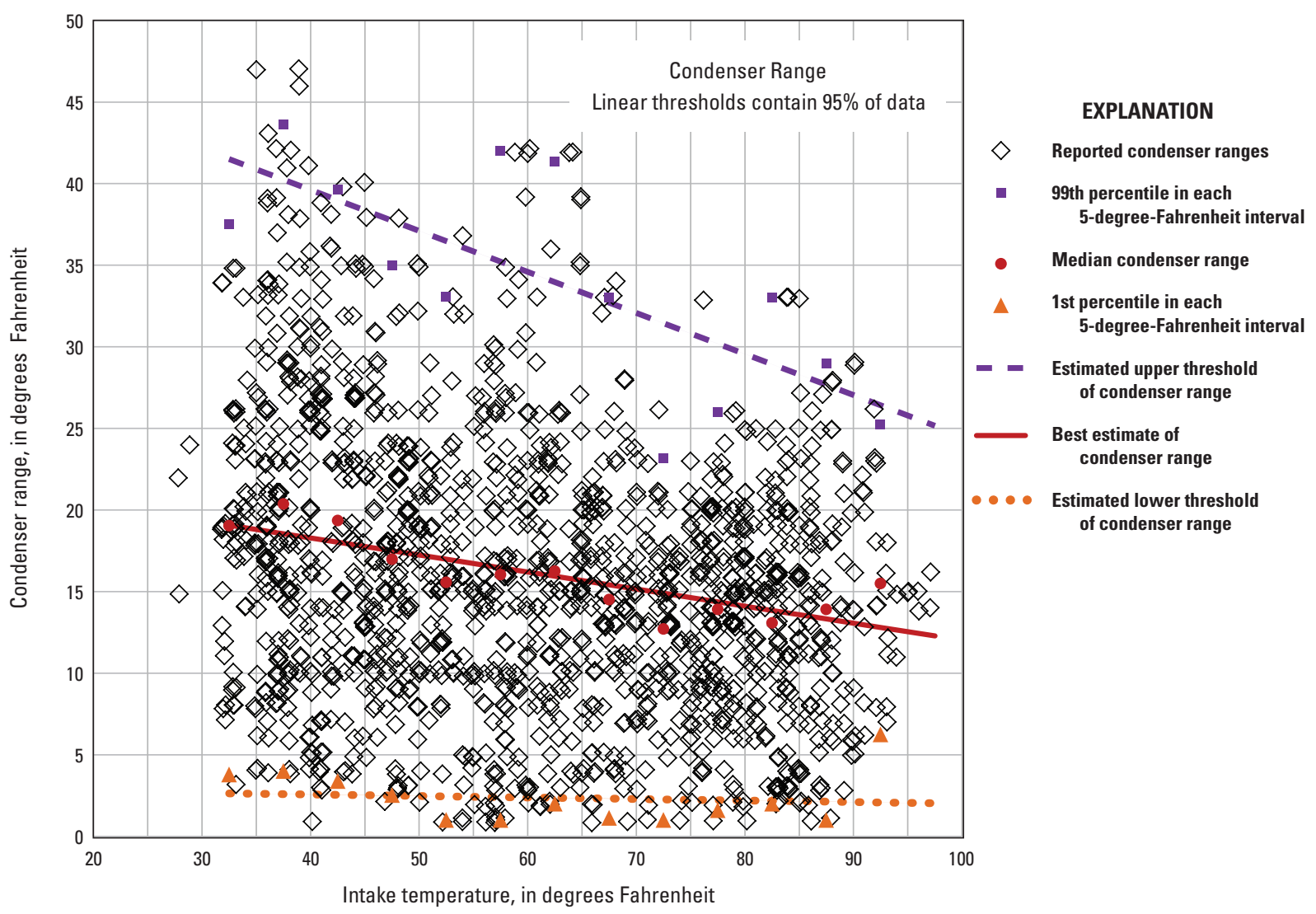

Figure 4. Median, minimum, and maximum estimated condenser ranges and reported condenser ranges for thermoelectric power plants in the United States. 


\section{Recirculating Pond Withdrawals}

The identification of a cooling pond as recirculating or once-through has a substantial effect on its withdrawal estimate. If identified as once-through, flow through the condenser(s) is defined by the USGS as withdrawal, and consumption is determined as forced evaporation from the pond. For ponds identified as recirculating systems, withdrawal is defined herein as the sum of makeup flows to replace water lost by natural pond evaporation and forced evaporation, which is equal to estimated consumption.

In practice, makeup flow may also be used to offset other unknown fluxes including pond leakage and blowdown (water discharged or "blown down" from the cooling system to limit the concentration of dissolved solids). Uncertainties in natural evaporation are large but were not quantified, nor were magnitudes of leakage and blowdown. The water level in a cooling pond can vary over time, and losses may not be made up as they occur. In States with appropriated water rights, water availability may limit makeup flows. Although makeup flows were calculated by month, even annual totals are subject to uncertainty due to differences in water level at the beginning and end of the year.

\section{Tower Withdrawals}

Withdrawal at plants with recirculating cooling towers is almost entirely cooling system makeup replacing evaporated water and blowdown. Other losses include a small amount of water lost as "drift" (droplets entrained in the air). Drift was assumed to be insignificant in the heat-budget model; in modern towers, drift is much smaller than the uncertainty in the modeled evaporation.

The amount of blowdown water used in tower cooling systems was calculated from the evaporative consumption from the tower and the cycles of concentration for the system. "Cycles of concentration" refers to the ratio of dissolvedsolids concentrations in blowdown discharge to concentrations in makeup water (withdrawal). The number of cycles of concentration is also about equal to the ratio of the makeup to blowdown. The more cycles of concentration, the less blowdown: at 2 cycles of concentration, a plant's blowdown is equal to its consumption, while at 10 cycles, blowdown is one-ninth of consumption. Although efficient operations at most sites would make it possible to operate at 5 to 8 cycles of concentration (California Utilities Statewide Codes and Standards Team, 2011), this may impose higher costs, and many plants still operate in the range of 2 to 4 cycles and as low as 1.5 cycles for cooling towers that use seawater. Thus, while withdrawal is typically 115 to 150 percent of consumption for freshwater towers, it can be as high as 200 percent. At some plants, blowdown water is disposed of in evaporation ponds instead of being treated and discharged, and the remaining solids are disposed of in landfills; this method of blowdown disposal was not modeled.

Three estimates of withdrawal for cooling towers were developed: a best estimate and lower and upper limits outside of which reported withdrawals are difficult to reconcile with heat and water budgets. The best estimate of tower withdrawal was 140 percent of median estimated tower consumption, based on the typical value of 3.5 cycles of concentration (California Utilities Statewide Codes and Standards Team, 2011). Known sources of error include estimation error for condenser duty and evaporation ratio, which are treated in the consumption model (Diehl and others, 2013), and error in the assumed cycles of concentration. To address the latter error, a Monte Carlo experiment (Efron and Efron, 1982) was run through about 1 million realizations, using a range of cycles of concentration from 2 to 10 . Ninety-five percent of realizations yielded withdrawals that fell between estimated minimum consumption multiplied by 1.29 and estimated maximum consumption multiplied by 1.77 . These values were taken as conservative limits for plausible tower withdrawal, assuming that error in the estimation of cycles of concentration is independent of other errors.

\section{Complex Plant Withdrawals}

Withdrawals at plants with more than one type of cooling system were estimated as a sum of withdrawal by each type. These component withdrawals were estimated separately using methods described above and were generally assumed to result from independent operations without interconnections. This assumption does not strictly apply in all cases. For example, discharge from once-through cooling systems may be used for makeup to recirculating systems, and this dual use may not be reflected in reported data. For a given amount of condenser duty, once-through withdrawal is much larger than recirculating withdrawal. Estimated withdrawals for complex plants that included once-through cooling systems were dominated by the once through component. Given that the uncertainty in estimating once-through withdrawal is greater than the magnitude of withdrawal for recirculating cooling at the same plant, the exact treatment of the recirculating withdrawal is unlikely to have a substantial effect on estimated plant withdrawal.

\section{Development of Consumption and Withdrawal Coefficients}

Consumption and withdrawal coefficients in gallons per kilowatt hour were estimated for the 892 simple plants. Consumption coefficients were estimated as the ratio of total annual consumption to annual net generation for all combinations of generation and cooling-system types.

Withdrawal coefficients were estimated in different ways for three types of cooling system. For once-through cooling systems, the withdrawal coefficient was calculated as the best estimate withdrawal divided by net generation. For recirculating ponds, the withdrawal coefficient equals the consumption coefficient. For recirculating cooling tower systems, withdrawal coefficients were computed as 1.4 times the corresponding consumption coefficient for each generation type, assuming 3.5 cycles of concentration. 
For all combinations of generation and cooling type, average annual consumption and withdrawal were divided by annual net generation to yield average consumption and withdrawal coefficients. These coefficients can be compared directly to published values, recognizing that not all published consumption coefficients take into account forced evaporation from the discharge plume below once-through cooling systems. Uncertainty in model predictions associated with high and low estimated threshold values for consumption at each plant is not reflected in these coefficients. Any systematic bias in the model would translate into systematic bias in the consumption coefficients presented here.

\section{Results and Discussion}

Model-based plant-specific estimates of thermoelectric water withdrawal and consumption for 2010 were the primary results of this study; they complement EIA-reported water use data for 2005 and 2010. These estimates and the coefficients of withdrawal and consumption developed from them were aggregated by plant category and compared between methods and between years. Alternative water use was evaluated for 2010. While the amount of withdrawal and consumption can be roughly defined and some trends are discernable, the differences between coefficients obtained using different methods suggest that thermoelectric water use is still subject to considerable uncertainty.

\section{Estimated Thermoelectric Water Use for 2010}

The national-level water-withdrawal total for 1,290 water-using thermoelectric plants in the United States estimated for 2010 was about $129 \mathrm{Bgal} / \mathrm{d}$ (table 6), of which about 3.5 Bgal/d, or about 3 percent, was consumed (table 7). Individual estimates of consumption and withdrawal for each plant are provided in appendix 1 (table available at http://pubs. usgs.gov/sir/2014/5184/). The largest estimated withdrawals occurred at plants using once-through cooling, accounting for 70 percent of annual withdrawals (table 6). Most once-through freshwater cooling systems are associated with coal-fired plants, whereas once-through saline water cooling systems are mostly at nuclear power plants. These findings are consistent with once-through cooling-system technologies and the large volumes of water needed for cooling purposes.

Excluding complex plants, recirculating cooling towers accounted for 60 percent of estimated consumption (table 7). The relatively large volumes of water consumed at plants with recirculating towers are consistent with the evaporative processes associated with this cooling-system technology.

\section{Consumption and Withdrawal Coefficients}

Withdrawal and consumption coefficients were calculated for only the 892 simple plants described above (tables 8 and 9). Though not derived from the full set of plants, these coefficients should be reasonably representative of water-use rates at all plants. Net generation at these plants amounted to 77 percent of total net generation for the 1,290 plants modeled for consumption and withdrawal.

Some of the consumption and withdrawal coefficients for simple plants developed in this study differ markedly from published values (Macknick and others, 2011). In particular, consumption coefficients developed by the heat-budget method for once-through cooling are at or above the highest published values, but most of those for cooling towers are at or below the lowest published values. Modeled consumption per kilowatt-hour of generation from plants with cooling towers exceeded that from plants with once-through systems by about 20 to 70 percent across the four cooling types.

\section{EIA-Reported Water Use in 2005 and 2010}

Total EIA-reported withdrawals decreased from $198 \mathrm{Bgal} / \mathrm{d}$ in 2005 to $163 \mathrm{Bgal} / \mathrm{d}$ in 2010, an 18-percent decline (table 6). In both years, withdrawals at simple plants with once-through freshwater cooling dominated by coalfired and nuclear plants accounted for just over half of total withdrawals (fig. 5; table 6). The largest declines in withdrawal (18.2 Bgal/d and 9.5 Bgal/d for freshwater and saline systems, respectively) occurred at once-through systems (fig. 5; table 6). Similarly, withdrawals for complex plants, most of which have cooling systems consisting of oncethrough cooling and recirculating towers, declined 31 percent (table 6). Because once-through cooling systems withdraw larger volumes of water than cooling towers, the decline at complex plants suggests a shift from once-through cooling to tower- cooling systems. Taken together, the decline in withdrawals at once-through saline, once-through fresh, and complex plants accounts for 96 percent of the total decrease in withdrawals, while the number of plants in all three categories remained nearly constant from 2005 to 2010 (U.S. Department of Energy, Energy Information Administration, 2006b and 2011b).

Natural gas combined-cycle (NGCC) plants, associated mostly with recirculating towers, represent the largest increase in net generation from 2005 to 2010 (fig. 6; table 3). Contrary to the overall trend, reported withdrawals for once-through cooling for NGCC plants increased fourfold between 2005 and 2010 (table 6). This proportional increase was relatively small in total magnitude (about $0.9 \mathrm{Bgal} / \mathrm{d}$ ) and may reflect use of recirculating towers in some new plants, conversion of older plants to NGCC generation without changes to existing cooling systems, or inconsistent reporting. 
Table 6. Thermoelectric plant water withdrawals by generation and cooling-system types as reported to the U.S. Department of Energy, Energy Information Administration (EIA) for 2005 and 2010, and as modeled by the U.S. Geological Survey (USGS) for 2010.

[Values may not sum to totals because of independent rounding. All withdrawal is in millions of gallons per day; NGCC, natural gas combined cycle; NA, not applicable; NR, not reported; Complex, geothermal and solar thermal plants and plants that have multiple cooling-system types, generation technologies, and/or use multiple fuels]

\begin{tabular}{|c|c|c|c|c|c|c|c|c|c|c|c|c|c|c|c|c|c|c|}
\hline \multirow{4}{*}{$\begin{array}{c}\text { Genera- } \\
\text { tion } \\
\text { type }\end{array}$} & \multicolumn{15}{|c|}{ Cooling-system type } & \multirow{2}{*}{\multicolumn{3}{|c|}{ Totals }} \\
\hline & \multicolumn{3}{|c|}{ Once-through saline } & \multicolumn{3}{|c|}{ Once-through fresh } & \multicolumn{3}{|c|}{ Recirculating pond } & \multicolumn{3}{|c|}{ Recirculating tower } & \multicolumn{3}{|c|}{ Complex } & & & \\
\hline & \multicolumn{2}{|c|}{ EIA } & \multirow{2}{*}{$\frac{\text { USGS }}{2010}$} & \multicolumn{2}{|c|}{ EIA } & \multirow{2}{*}{$\begin{array}{c}\text { USGS } \\
2010\end{array}$} & \multicolumn{2}{|c|}{ EIA } & \multirow{2}{*}{$\begin{array}{c}\text { USGS } \\
2010\end{array}$} & \multicolumn{2}{|c|}{ EIA } & \multirow{2}{*}{$\frac{\text { USGS }}{2010}$} & \multicolumn{2}{|c|}{ EIA } & \multirow{2}{*}{$\begin{array}{c}\text { USGS } \\
2010\end{array}$} & \multicolumn{2}{|c|}{ EIA } & \multirow{2}{*}{$\begin{array}{c}\text { USGS } \\
2010\end{array}$} \\
\hline & 2005 & 2010 & & 2005 & 2010 & & 2005 & 2010 & & 2005 & 2010 & & 2005 & 2010 & & 2005 & 2010 & \\
\hline Oil & 5,037 & 1,349 & 659 & 998 & 35 & 21 & NR & NR & NA & 13 & 1 & 1 & NA & NA & NA & 6,048 & 1,385 & 681 \\
\hline Nuclear & 16,998 & 12,357 & 17,019 & 20,638 & 21,815 & 15,405 & 1,177 & 5,246 & 166 & 578 & 1,076 & 605 & NA & NA & NA & 39,392 & 40,494 & 33,196 \\
\hline NGCC & NR & 1,402 & 1,213 & 292 & 1,188 & 446 & 15 & 102 & 16 & 1,038 & 643 & 384 & NA & NA & NA & 1,346 & 3,334 & 2,060 \\
\hline Gas steam & 14,652 & 10,533 & 1,209 & 9,661 & 5,952 & 2,442 & 1,073 & 1,631 & 21 & 102 & 50 & 32 & NA & NA & NA & 25,488 & 18,166 & 3,704 \\
\hline Coal & 3,843 & 5,413 & 2,363 & 71,359 & 55,736 & 49,489 & 5,058 & 7,742 & 187 & 3,422 & 1,497 & 1,259 & NA & NA & NA & 83,682 & 70,388 & 53,298 \\
\hline Complex & NA & NA & NA & NA & NA & NA & NA & NA & NA & NA & NA & NA & 42,180 & 29,272 & 35,753 & 42,180 & 29,272 & 35,753 \\
\hline Totals & 40,530 & 31,054 & 22,463 & 102,948 & 84,725 & 67,803 & 7,324 & 14,720 & 390 & 5,153 & 3,268 & 2,283 & 42,180 & 29,272 & 35,753 & 198,136 & 163,039 & 128,692 \\
\hline
\end{tabular}

Table 7. Thermoelectric plant water consumption by generation and cooling-system types as reported to the U.S. Department of Energy, Energy Information Administration (EIA) for 2005 and 2010, and as modeled by the U.S. Geological Survey (USGS) for 2010.

[Values may not sum to totals because of independent rounding. All consumption is in millions of gallons per day; NGCC, natural gas combined cycle; NR, not reported; NC, not calculated; NA, not applicable; Complex, geothermal and solar thermal plants and plants that have multiple cooling-system types, generation technologies, and/or use multiple fuels]

\begin{tabular}{|c|c|c|c|c|c|c|c|c|c|c|c|c|c|c|c|c|c|c|}
\hline \multirow{4}{*}{$\begin{array}{c}\text { Genera- } \\
\text { tion } \\
\text { type }\end{array}$} & \multicolumn{15}{|c|}{ Cooling-system type } & \multirow{2}{*}{\multicolumn{3}{|c|}{ Totals }} \\
\hline & \multicolumn{3}{|c|}{ Once-through saline } & \multicolumn{3}{|c|}{ Once-through fresh } & \multicolumn{3}{|c|}{ Recirculating pond } & \multicolumn{3}{|c|}{ Recirculating tower } & \multicolumn{3}{|c|}{ Complex } & & & \\
\hline & \multicolumn{2}{|c|}{ EIA } & \multirow{2}{*}{$\begin{array}{c}\text { USGS } \\
2010\end{array}$} & \multicolumn{2}{|c|}{ EIA } & \multirow{2}{*}{$\frac{\text { USGS }}{2010}$} & \multicolumn{2}{|c|}{ EIA } & \multirow{2}{*}{$\begin{array}{c}\text { USGS } \\
2010\end{array}$} & \multicolumn{2}{|c|}{ EIA } & \multirow{2}{*}{$\frac{\text { USGS }}{2010}$} & \multicolumn{2}{|c|}{ EIA } & \multirow{2}{*}{$\begin{array}{c}\text { USGS } \\
2010\end{array}$} & \multicolumn{2}{|c|}{ EIA } & \multirow{2}{*}{$\frac{\text { USGS }}{2010}$} \\
\hline & 2005 & 2010 & & 2005 & 2010 & & 2005 & 2010 & & 2005 & 2010 & & 2005 & 2010 & & 2005 & 2010 & \\
\hline Oil & NR & NR & $\mathrm{NC}$ & NR & 25 & 0.2 & NR & NR & NA & 12 & 0.4 & 0.8 & NA & NA & NA & 12 & 25 & 1 \\
\hline Nuclear & NR & NR & $\mathrm{NC}$ & 219 & 236 & 157 & 168 & 64 & 166 & 414 & 384 & 433 & NA & NA & NA & 801 & 684 & 756 \\
\hline NGCC & NR & 15 & $\mathrm{NC}$ & NR & 0.3 & 5 & 7 & 0.2 & 16 & 600 & 334 & 268 & NA & NA & NA & 606 & 350 & 288 \\
\hline Gas steam & NR & 38 & $\mathrm{NC}$ & 28 & 30 & 27 & 103 & 3 & 21 & 62 & 42 & 23 & NA & NA & NA & 193 & 113 & 71 \\
\hline Coal & NR & NR & $\mathrm{NC}$ & 210 & 288 & 503 & 183 & 370 & 187 & 2,164 & 835 & 867 & NA & NA & NA & 2,557 & 1,493 & 1,557 \\
\hline Complex & NR & NA & NA & NA & NA & NA & NA & NA & NA & NA & NA & NA & 793 & 603 & 832 & 793 & 603 & 832 \\
\hline Totals & NR & 53 & $\mathrm{NC}$ & 456 & 579 & 692 & 462 & 437 & 390 & 3,251 & 1,596 & 1,591 & 793 & 603 & 832 & 4,962 & 3,268 & 3,505 \\
\hline
\end{tabular}


Table 8. Thermoelectric water-withdrawal coefficients calculated from flow rates and net electrical generation as reported to the U.S. Department of Energy, Energy Information Administration (EIA) and as calculated from modeled estimates by the U.S. Geological Survey (USGS) for 2010.

[All coefficients are in gallons per killowatt hour; NGCC, natural gas combined cycle; NR, not reported; NA, not applicable]

\begin{tabular}{|c|c|c|c|c|c|c|c|c|c|c|c|c|}
\hline \multirow{4}{*}{$\begin{array}{c}\text { Genera- } \\
\text { tion } \\
\text { type }\end{array}$} & \multicolumn{12}{|c|}{ Cooling-system type } \\
\hline & \multicolumn{3}{|c|}{ Once-through saline } & \multicolumn{3}{|c|}{ Once-through fresh } & \multicolumn{3}{|c|}{ Recirculating pond } & \multicolumn{3}{|c|}{ Recirculating tower } \\
\hline & \multicolumn{2}{|c|}{ EIA } & \multirow{2}{*}{$\begin{array}{c}\text { USGS } \\
2010\end{array}$} & \multicolumn{2}{|c|}{ EIA } & \multirow{2}{*}{$\begin{array}{c}\text { USGS } \\
2010\end{array}$} & \multicolumn{2}{|c|}{ EIA } & \multirow{2}{*}{$\begin{array}{c}\text { USGS } \\
2010\end{array}$} & \multicolumn{2}{|c|}{ EIA } & \multirow{2}{*}{\begin{tabular}{|c|} 
USGS \\
2010
\end{tabular}} \\
\hline & 2005 & 2010 & & 2005 & 2010 & & 2005 & 2010 & & 2005 & 2010 & \\
\hline Oil & 78 & 101 & 47 & 71 & 177 & 56 & NR & NR & NA & 12.75 & 1.6 & 0.99 \\
\hline Nuclear & NR & 28 & 39 & NR & 37 & 39 & NR & 22.24 & 0.78 & NR & 1.44 & 0.81 \\
\hline NGCC & NR & 15 & 14 & 209 & 26 & 11 & 0.59 & 7.78 & 0.35 & 2.61 & 0.54 & 0.29 \\
\hline Gas steam & 343 & 339 & 38 & 209 & 107 & 39 & 41.95 & 75.87 & 2.19 & 2.32 & 1.45 & 0.82 \\
\hline Coal & 44 & 59 & 32 & 40 & 37 & 32 & 14.46 & 23.01 & 0.65 & 1.84 & 0.75 & 0.63 \\
\hline
\end{tabular}

Table 9. Thermoelectric water-consumption coefficients calculated from flow rates and net electrical generation as reported to the U.S. Department of Energy, Energy Information Administration (EIA) and as calculated from modeled estimates by the U.S. Geological Survey (USGS) for 2010.

[All coefficients are in gallons per killowatt hour; NGCC, natural gas combined cycle; NR, not reported; NC, not calculated; NA, not applicable]

\begin{tabular}{|c|c|c|c|c|c|c|c|c|c|c|c|c|}
\hline \multirow{4}{*}{$\begin{array}{c}\text { Genera- } \\
\text { tion } \\
\text { type }\end{array}$} & \multicolumn{12}{|c|}{ Cooling-system type } \\
\hline & \multicolumn{3}{|c|}{ Once-through saline } & \multicolumn{3}{|c|}{ Once-through fresh } & \multicolumn{3}{|c|}{ Recirculating pond } & \multicolumn{3}{|c|}{ Recirculating tower } \\
\hline & \multicolumn{2}{|c|}{ EIA } & \multirow{2}{*}{$\frac{\text { USGS }}{2010}$} & \multicolumn{2}{|c|}{ EIA } & \multirow{2}{*}{$\begin{array}{c}\text { USGS } \\
2010\end{array}$} & \multicolumn{2}{|c|}{ EIA } & \multirow{2}{*}{$\begin{array}{c}\text { USGS } \\
2010\end{array}$} & \multicolumn{2}{|c|}{ EIA } & \multirow{2}{*}{$\begin{array}{c}\text { USGS } \\
2010\end{array}$} \\
\hline & 2005 & 2010 & & 2005 & 2010 & & 2005 & 2010 & & 2005 & 2010 & \\
\hline Oil & NR & NR & $\mathrm{NC}$ & NR & 125.33 & 0.59 & NR & NR & NA & 12.21 & 0.71 & 0.70 \\
\hline Nuclear & NR & NR & $\mathrm{NC}$ & NR & 0.4 & 0.4 & NR & 0.27 & 0.78 & NR & 0.51 & 0.58 \\
\hline NGCC & NR & 0.16 & $\mathrm{NC}$ & NR & 0.01 & 0.12 & 0.26 & 0.02 & 0.35 & 1.51 & 0.28 & 0.20 \\
\hline Gas steam & NR & 1.22 & $\mathrm{NC}$ & 0.59 & 0.54 & 0.44 & 4.03 & 0.13 & 2.19 & 1.4 & 1.22 & 0.58 \\
\hline Coal & NR & NR & $\mathrm{NC}$ & 0.12 & 0.19 & 0.33 & 0.52 & 1.1 & 0.65 & 1.17 & 0.42 & 0.43 \\
\hline
\end{tabular}

Total EIA-reported consumption declined $1.7 \mathrm{Bgal} / \mathrm{d}$ from 2005 to 2010 (table 7), a 34-percent decrease. Reported consumption for plants with tower cooling systems declined for all generation types (fig. 7), with a 61-percent decrease at coal-fired plants. The reduction in consumption at cooling towers is hard to reconcile with (1) the increased share of net electrical generation for plants with tower cooling systems (fig. 6; table 3), (2) a 33-percent increase from 2005 to 2010 in the number of tower plants that reported water use to the EIA (U.S. Department of Energy, Energy Information Administration, 2006b and 2011b), and (3) the relatively large volumes of water consumed through evaporation associated with tower cooling technology (Macknick and others, 2011). Similarly, reported consumption for once-through freshwater cooling systems increased while net generation decreased (figs. 6 and 7; tables 3 and 7).

Withdrawal and consumption coefficients computed based on EIA-reported information (tables 8 and 9) vary considerably among plant categories and reporting years; of the 23 pairs of coefficients that can be compared between 2005 and 2010, 12 increased or decreased by more than a factor of 2 . As noted earlier, reported withdrawals declined for simple plants from 2005 to 2010 while net generation increased overall, and nearly all decreases in withdrawal for individual categories were reflected in a decrease in the withdrawal coefficient for that category (tables 6 and 8).

Most of the decline in consumption at simple plants was at coal plants with recirculating towers, and was associated with an unexplained 64-percent decrease in the consumption coefficient for these plants (table 9). The decrease in the consumption coefficient for coal plants with towers was intermediate between larger decreases for oil and NGCC plants, and smaller decreases for nuclear and gas steam plants. Similar to the USGS-modeled coefficients discussed above, several consumption coefficients derived from EIA-reported data for both 2005 and 2010 lie outside the ranges reported by Macknick and others (2011).

Large changes in withdrawal and consumption coefficients between 2005 and 2010 were the rule rather than the exception. Such changes are physically possible with great increases or decreases in the thermal efficiency of generation 


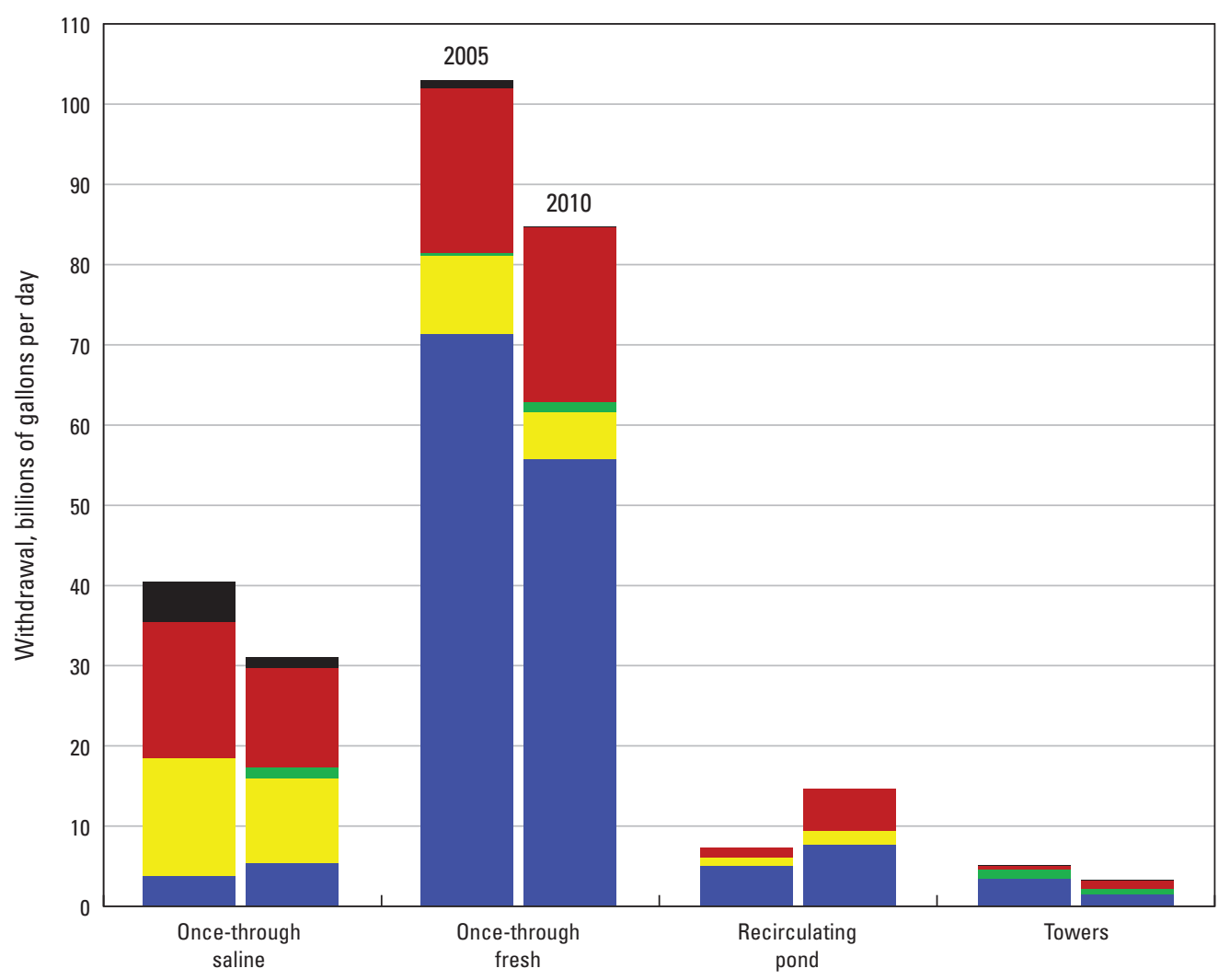

\section{EXPLANATION \\ Generation type \\ oil \\ Nuclear \\ NGCC \\ Gas steam \\ Coal}

Figure 5. Water withdrawal by generation type and cooling-system type for simple thermoelectric power plants, 2005 and 2010. [Data reported to the U.S. Department of Energy, Energy Information Administration; NGCC, natural gas combined cycle]

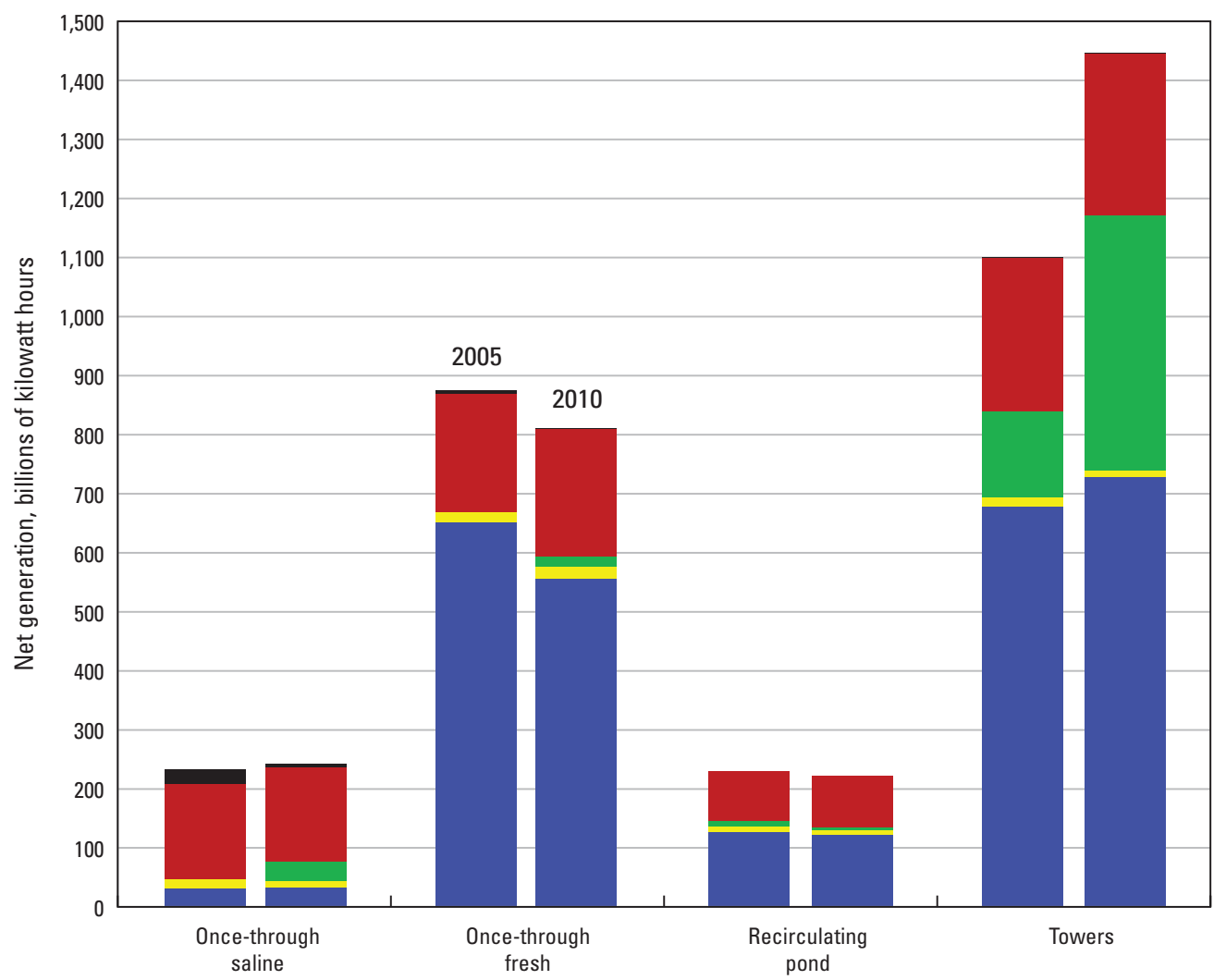

\section{EXPLANATION}

Generation type

$\square$ oil

Nuclear

NGCC

Gas steam

Coal

Figure 6. Net electrical generation by generation type and cooling-system type for simple thermoelectric power plants, 2005 and 2010. [Data reported to the U.S. Department of Energy, Energy Information Administration; NGCC, natural gas combined cycle] 


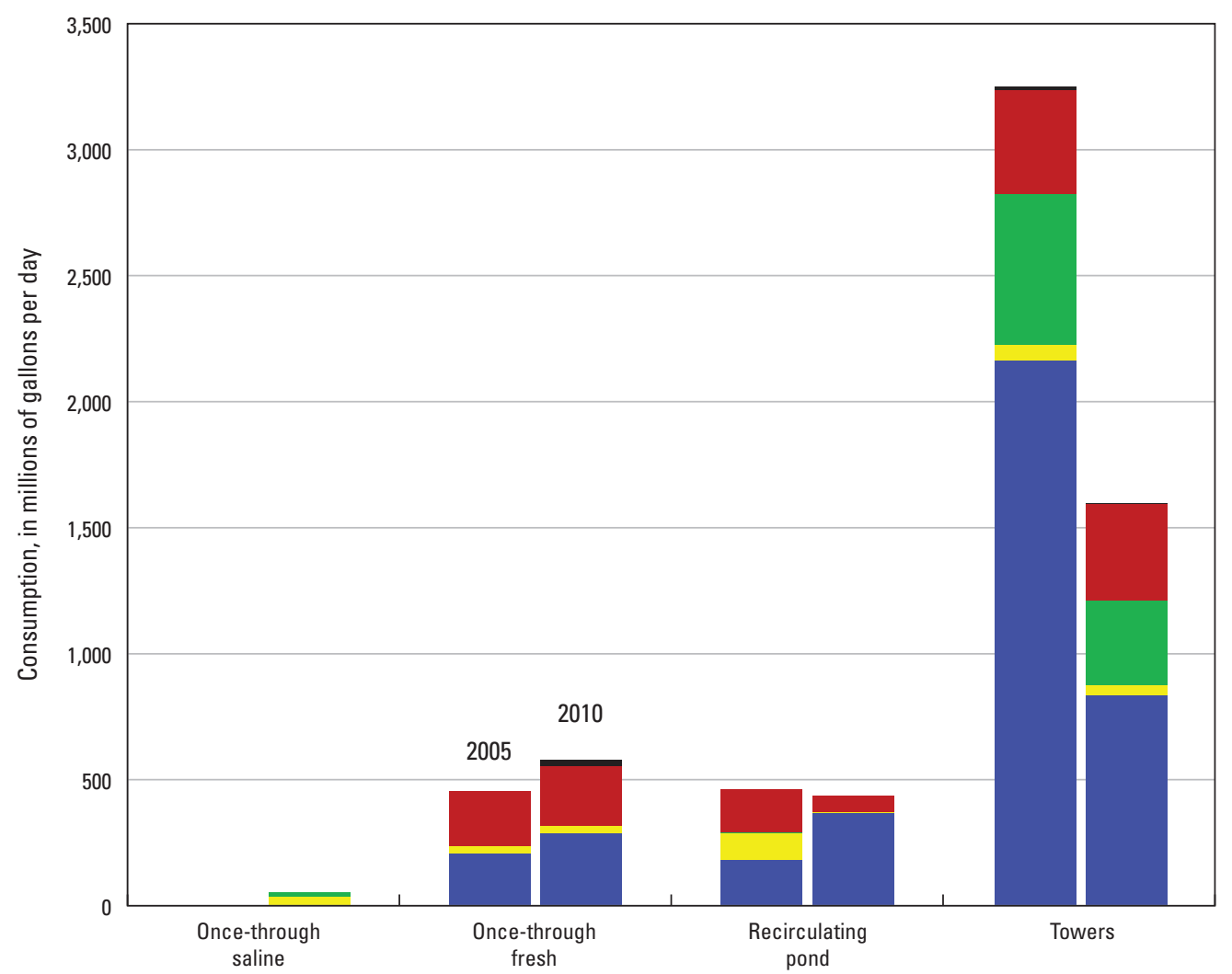

\author{
EXPLANATION \\ Generation type \\ oil \\ Nuclear \\ NGCC \\ Gas steam \\ Coal
}

Figure 7. Water consumption by generation type and cooling-system type for simple thermoelectric power plants, 2005 and 2010. [Data reported to the U.S. Department of Energy, Energy Information Administration; NGCC, natural gas combined cycle] or the water efficiency of cooling systems. However, most of the technology involved in thermoelectric water use is mature, and efficiency changes only gradually as new plants and cooling systems replace old ones within each plant category. Overall, the best explanation for the changing coefficients from 2005 to 2010 may not be technological factors, but rather changes in definitions and reporting practices.

\section{Alternative Water}

Alternative water use has potential to offset withdrawal and consumption of water otherwise suited to meet a broad range of socioeconomic and environmental uses. Unfortunately the assessment of that potential requires addressing a number of definitional issues. For example, EIA survey forms recognize five distinct water types (table 5) but do not include definitions, leaving coding to the interpretation of plant operators. The USGS defines "saline water" as water having dissolved-solids concentrations too high for human consumption or irrigation, with a lower threshold of 1,000 milligrams per liter (mg/L) - about 1/35 the salinity of seawater (U.S. Geological Survey, 2013), likely including most or all water reported by the EIA as "brackish." The EIA reports consumption of saline and brackish water, whereas the USGS generally regards evaporation of such water as a negligible component of global and national water budgets and does not estimate such consumption. The EIA reports delivery of water from a treatment plant to a power plant as a withdrawal, but such delivery does not meet the USGS definition of withdrawal as coming from a natural hydrologic system. To facilitate comparison of EIA-reported and USGS-estimated alternative water use, the EIA usage for withdrawal and consumption is used in this section.

EIA-reported and USGS-estimated alternative-water withdrawals for 2010 were about 40 and $30 \mathrm{Bgal} / \mathrm{d}$, respectively (fig. 8). These withdrawals represent about one-quarter of the respective national totals for reported and estimated thermoelectric withdrawals (table 6). Saline and brackish water types constitute about 95 percent of EIA-reported withdrawal, and saline water type is about 98 percent of USGS-estimated withdrawals (fig. 8). More than 95 percent of reported or estimated saline or brackish withdrawals were taken from surface-water sources for once-through cooling systems (appendix 1). Reclaimed wastewater, such as treated sewage effluent, is less than 1 percent of alternative water withdrawals and about a third of that use is at one plant, Palo Verde in Arizona (appendix 1).

In comparison to withdrawals, alternative-water consumption was relatively small in 2010. Reported and estimated alternative-water consumption, 294 and $169 \mathrm{Mgal} / \mathrm{d}$, respectively (fig. 9), represents less than 1 percent of alternativewater withdrawals and less than 10 percent of national total consumption (figs. 8 and 9; table 7). 
$\boldsymbol{A}$

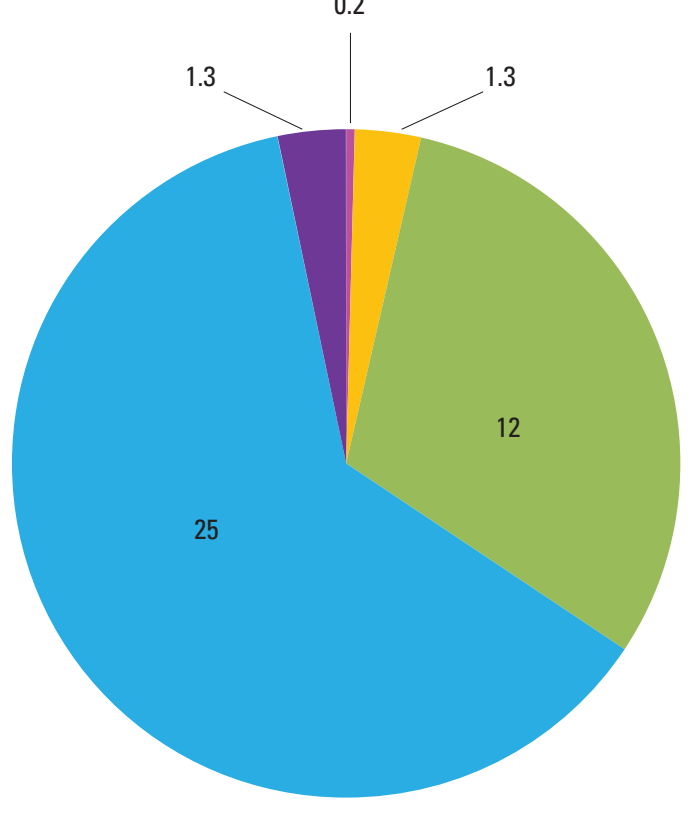

$\mathrm{EIA}=40 \mathrm{Bgal} / \mathrm{d}$
B

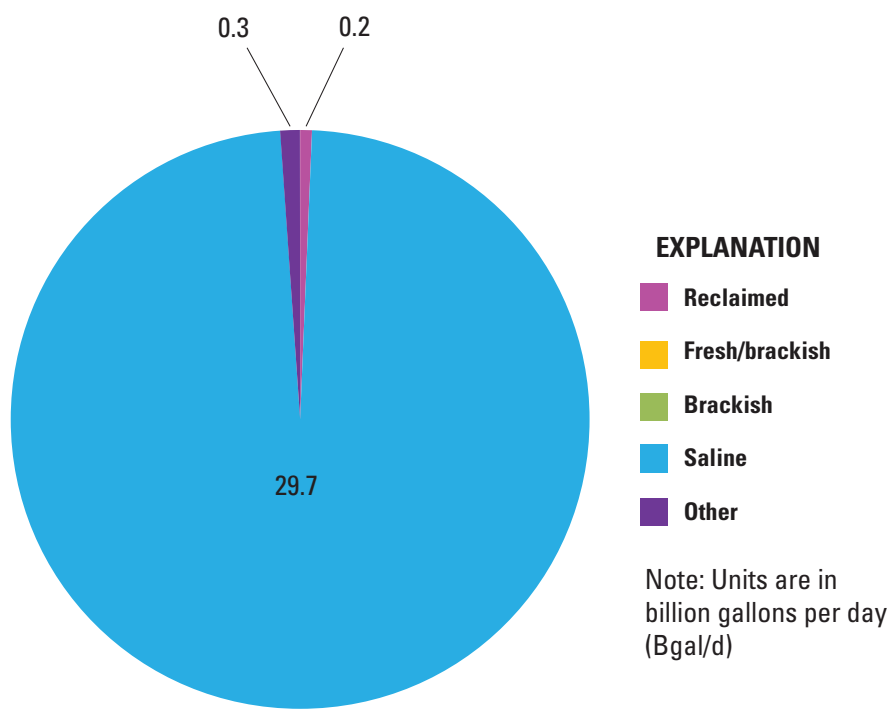

USGS $=30 \mathrm{Bgal} / \mathrm{d}$

Figure 8. Alternative water withdrawals by thermoelectric plants in the United States as $(A)$ reported to the U.S. Department of Energy, Energy Information Administration (EIA), and (B) estimated by the U.S. Geological Survey (USGS), 2010.

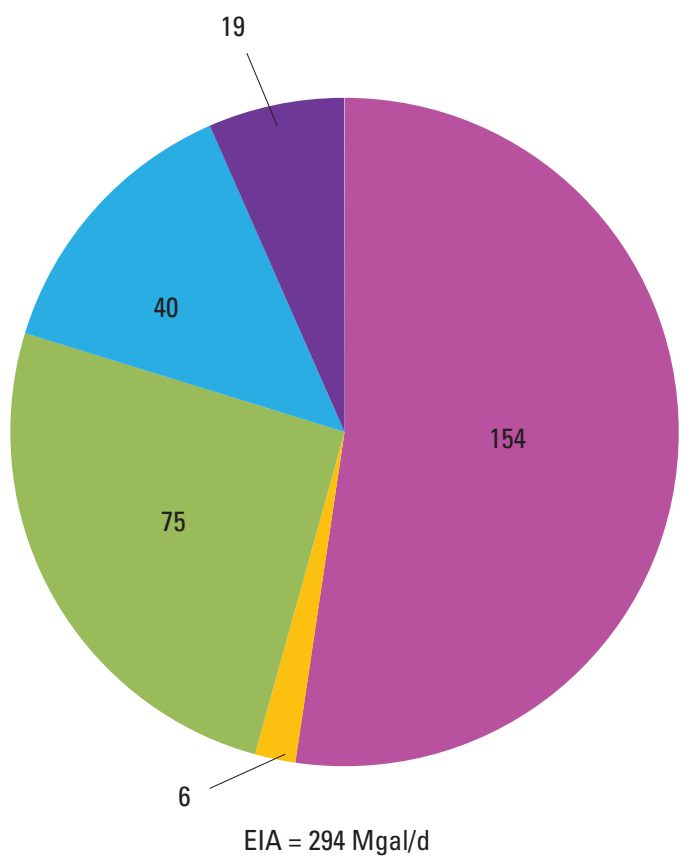

B

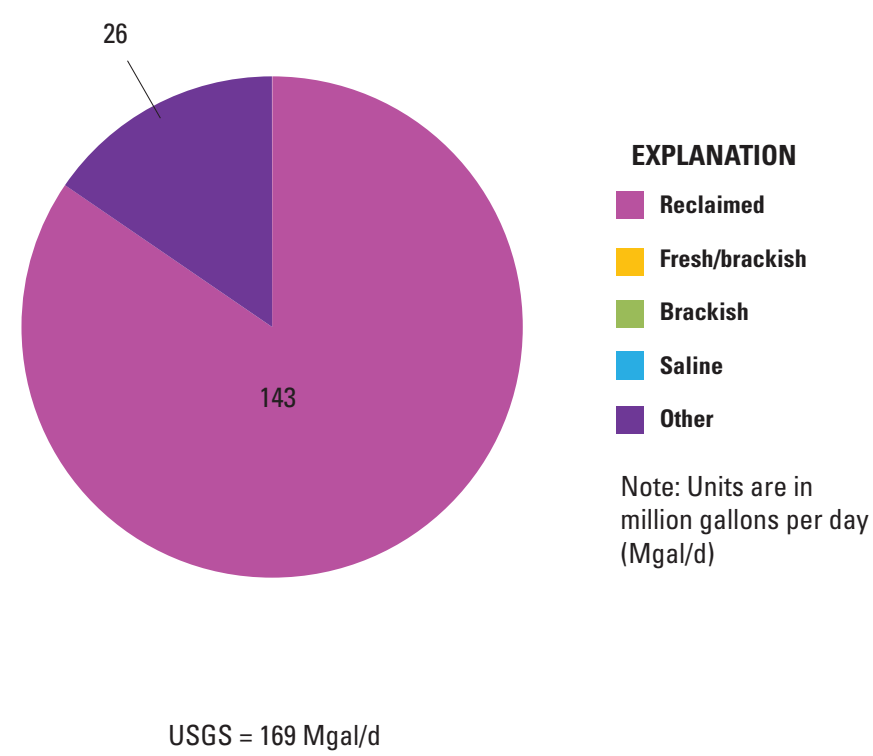

Figure 9. Alternative water consumption by thermoelectric plants in the United States as $(A)$ reported to the U.S. Department of Energy, Energy Information Administration (EIA), and (B) estimated by the U.S. Geological Survey (USGS), 2010. 
The most striking difference between alternative-water withdrawal and consumption is in the relative contributions of different water types. Reclaimed water represents 1 percent or less of reported and estimated alternative water withdrawal but 52 and 85 percent of respective consumption (fig. 9). This inversion of the relative importance of reclaimed water largely reflects uneven reporting of consumption as it applies to saline and brackish waters. Of 104 plants reporting withdrawal of such water to the EIA, only 26 plants reported consumption, while the USGS did not estimate consumption for any plants reporting saline or brackish water types. If saline and brackish water types are ignored, reported and estimated alternative water consumption numbers conform fairly well, totaling to 173 and $169 \mathrm{Mgal} / \mathrm{d}$, respectively (fig. 9). Almost all of the plants using reclaimed wastewater use recirculating towers for cooling (appendix 1).

\section{Comparison of EIA 2010 Data to USGS Model Results}

The national withdrawal estimated from heat-budget models for 2010 was about 21 percent lower than the withdrawal based on EIA-reported data; in contrast, the modelbased consumption total was about 9 percent higher than the EIA-based total consumption. Differences between reported and estimated totals are inconsistent among individual plant categories. As an example, estimated withdrawal was 38 percent more than reported withdrawal for once-through saline simple nuclear plants, whereas estimated withdrawal was 29 to 97 percent less than reported withdrawal for other cooling types (table 6).

Comparison with heat-budget model results identified a few plants with reported withdrawals too high to be easily explained thermodynamically; these relatively few plants contributed most of the difference between national totals for reported and estimated withdrawal. Differences between USGS- and EIA-based coefficients reflect differences in definitions, difficulties in measuring, and possibly errors in reported information. Improved information from just a few plants might greatly increase the accuracy of coefficients and aggregate values calculated from EIA-reported information.

Of the 1,290 plants for which withdrawals were modeled, 736 reported non-zero withdrawal to the EIA. These 736 plants produced 88 percent of the total net generation at the 1,290 plants, of which only two-thirds was produced by plants reporting withdrawals within the minimum and maximum of estimated withdrawals. At 132 plants, representing 13 percent of the total net generation at the 1,290 plants, EIA-reported withdrawals were higher than the maximum thermodynamically plausible values based on heat-budget models. Reported withdrawals at these plants were about $25 \mathrm{Bgal} / \mathrm{d}$, while modeled best estimates totaled $1 \mathrm{Bgal} / \mathrm{d}$ and maximum withdrawals with margins of uncertainty totaled about $3 \mathrm{Bgal} / \mathrm{d}$. The excess of reported withdrawals of about
$22 \mathrm{Bgal} / \mathrm{d}$ above maximum modeled estimates is difficult to reconcile with heat budgets, even with compensating assumptions. Of this excess, 32 percent is reported from a single plant, El Segundo Power in Los Angeles (appendix 1) and an additional 48 percent is associated with 9 other plants. Together these 10 plants represent more than half of the difference between EIA-reported withdrawal and USGS-estimates, and their total reported withdrawal was 32 times larger than the total of USGS-estimated maximum withdrawal for the same plants.

Coefficients based on withdrawals reported to EIA were higher than withdrawal coefficients estimated from heatand water-budget models for several plant types (table 8). Reported withdrawal at recirculating ponds exceeded estimated withdrawal across all generation types, reflecting similar differences in withdrawal coefficients. Some large withdrawals reported to the EIA for recirculating ponds appear to be flows through condensers rather than makeup flows to ponds. Currently, EIA form 923 allows reporting such flows as withdrawal at recirculating ponds, and the values reported are large enough to support this inference. Because the USGS defines withdrawal as water taken from a natural hydrologic system, only makeup flow is included in USGS-modeled coefficients. As a result, USGS withdrawal coefficients for recirculating ponds are predictably lower than those based on EIA-reported withdrawals.

Based on comparison to USGS estimates, most thermoelectric generation in 2010 is not associated with thermodynamically plausible EIA-reported values of both withdrawal and consumption. Those plants reporting values greater than zero to EIA contributed 70 percent of 2010 net generation, and those also reporting values between modeled minima and maxima contributed only 33 percent of net generation for plants with estimated consumption (appendix 1). Likewise, those plants reporting non-zero values for both withdrawal and consumption contributed 69 percent of net generation and those also reporting values between modeled minima and maxima contributed only 25 percent of net generation for plants with estimated consumption (appendix 1).

Consumption coefficients based on EIA data for recirculating ponds were low relative to USGS estimates for the same plant types, except for coal-fired plants (table 9). Estimated consumption coefficients for recirculating ponds were higher than those for towers within each generation type. In contrast, coefficients computed from EIA-reported consumption were lower for recirculating ponds than for towers for all generation types other than coal-fired plants.

For once-through consumption, differences between USGS-estimated and EIA-based coefficients were inconsistent, reflecting the lack of a single recommended method for estimating such consumption for reporting to the EIA. Consumption coefficients for towers were in general agreement between EIA-reported data and the USGS models, except at gas-fired steam plants where the EIA-based coefficient is higher than the model-based coefficient (table 9). 
Even though large differences exist within plant categories, the total EIA-reported consumption was only 8 percent less than that estimated from heat- and water-budget models (table 7). Reported consumption was lower than estimated consumption for once-through cooling systems and for all towers except those at gas-fired plants. Definitional differences, measurement difficulties, and reporting practices may all contribute to these differences.

\section{Conclusions}

The heat-budget approach offers a new perspective on estimating thermoelectric water use. Models of heat and water flows in power plants are based on simplifying assumptions about plant technology and evaporation processes. Although these models rely on information about plant technology, fuel use, and electric generation reported to the U.S. Department of Energy, Energy Information Administration (EIA), they provide independent estimates of water use. The models used in this investigation produced average withdrawal and consumption coefficients that are inconsistent with previously published values for several combinations of generation technology and cooling type, expanding the already broad range of estimated coefficients for several plant types.

Examination of EIA data for simple plants shows that water withdrawals declined considerably from 2005 to 2010. Most of the decline can be attributed to coal-fired plants with oncethrough cooling systems. The data also indicate that the share of net electrical generation increased at plants using recirculating towers for cooling, the largest increase occurring at natural gas combined cycle plants. These findings may reflect conversion from once-through to recirculating-tower cooling, and new, more efficient plants using tower cooling coming online.
Although reported and modeled withdrawals of alternative water types are somewhat inconsistent, both indicate that most alternative water withdrawals are seawater and tidal brackish water for once-through cooling. Reclaimed wastewater, such as treated sewage effluent, is less than 1 percent of alternative water withdrawals and about a third of that use is at one plant.

Consumption and withdrawal coefficients based on reported water use show inconsistent results between years, among plant categories, and with values in the published literature. Changes to the EIA forms in 2010 may have contributed to the inconsistencies between 2005 and 2010 results.

Heat-budget models produced a lower estimate of national total thermoelectric withdrawal and a higher estimate of consumption than EIA-reported values. Most thermoelectric generation in 2010 is not associated with thermodynamically plausible EIA-reported values of both withdrawal and consumption. Ratios of reported to modeled values at individual plants vary widely.

Uncertainties can be reduced by improvements in measuring and reporting water flows at plants, refinements in modeling evaporation and withdrawal, and improved environmental data collection at thermoelectric plants. In particular, consumption by once-through systems cannot be measured directly, and modeling such consumption would benefit from better information on surface-water temperatures.

In principle, both the heat budget approach and the practice of reporting withdrawal and consumption are valid ways to estimate thermoelectric water use, but both methods need to be refined. Inconsistencies in results suggest that actual uncertainty in thermoelectric water use is on the order of 10 to 20 percent or more for national totals and much more for individual plants. Examination of the differences among various coefficients that represent the same flow at the same type of plant may illuminate methodological issues that need to be resolved in order to improve estimates of thermoelectric water use. 


\section{Selected References}

Allen, R.G., Pereira, L.S., Raes, D., and Smith, M., 1998, Crop evapotranspiration - Guidelines for computing crop water requirements: Rome, Food and Agriculture Organization of the United Nations Irrigation and Drainage Paper 56.

Anderson, E.R., 1954, Water-loss investigations-Lake Hefner studies, technical report: U.S. Geological Survey Professional Paper 269, 158 p.

Ashwood, A., and Bharathan, D., 2011, Hybrid cooling systems for low-temperature geothermal power production: Denver, Colorado, National Renewable Energy Laboratory, NREL/TP-5500-48765, 62 p.

Brady, D.K., Graves, W.L., and Geyer, J.C., 1969, Surface heat exchange at power plant cooling lakes, report 5: Baltimore, Maryland, The Johns Hopkins University Department of Geography and Engineering, 154 p.

Breiman, L., and Spector, P., 1992, Submodel selection and evaluation in regression-The $\mathrm{x}$-random case: International Statistical Review, v. 60, no. 3, p. 291-319.

Cade, B.S., and Noon, B.R., 2003, A gentle introduction to quantile regression for ecologists: Frontiers in Ecology and the Environment, v. 1, p. 412-420.

California Energy Commission, 2005, A preliminary environmental profile of California's imported electricity: California Energy Commission staff report prepared in support of the 2005 Integrated Energy Policy Report, 71 p., accessed April 23, 2013, at http://www.energy. ca.gov/2005publications/CEC-700-2005-017/CEC-7002005-017.PDF.

California Utilities Statewide Codes and Standards Team, 2011, Cooling tower water savings, 2013 California Building Energy Efficiency Standards, accessed July 19, 2014, at http://www.energy.ca.gov/title24/2013standards/ prerulemaking/documents/current/Reports/Nonresidential/ HVAC/2013_CASE_WS4-CTWS_10.5.2011.pdf.

Cheremisinoff, N.P., and Cheremisinoff, P.N., 1981, Cooling towers selection, design and practice: Ann Arbor, Michigan, Ann Arbor Science Publishers, 347 p.

Clark, C.E., Harto, C.B., Sullivan, J.L., and Wang, M.Q., 2010, Water use in the development and operation of geothermal power plants: Argonne, Illinois, Argonne National Laboratory, ANL/EVS/R-10/5, 74 .

Cohen G.E., Kearney, D.W., and Kolb, G.J., 1999, Final report on the operation and maintenance improvement program for concentrating solar power plants: Albuquerque, New Mexico, Sandia National Laboratories (SNL), and Livermore, California, Lawrence Livermore National Laboratory, No. SAND99-1290, 186 p.
Cooling Technology Institute, 2010, Recommendations for winter operations of water cooling towers, chap. 4 of Cooling Tower Manual: Houston, Texas, Cooling Technology Institute, $16 \mathrm{p}$.

Cronshey, R., 1986, Urban hydrology for small watersheds ( $2 \mathrm{~d}$ ed.): U.S. Department of Agriculture, Soil Conservation Service, Engineering Division, 210-VI-TR-55, 164 p.

Dagdas, A., Erdem, H.H., and Sevilgen, S.H., 2005, Performance analysis of gas turbine integrated geothermal power plant in Turkey-The proposed Kizildere project: Antalya, Turkey, Proceedings, World Geothermal Congress, p. 24-29.

Dahle, D., Sr., 2008, Solar technology, BLM-Arizona Lands Training (June 25, 2008), accessed February 16, 2013, at http://www.blm.gov/pgdata/etc/medialib/blm/wo/MINERALS_REALTY_AND_RESOURCE_PROTECTION_I energy/renewable_references.Par.63109.File.dat/Solar percent20Energy--AZ percent20Lands percent20Training percent2006.25.08.pdf.

Dennen, B., Larson, D., Lee, C., Lee, J., and Tellinghuisen, S., 2007, California's energy-water nexus-Water use in electricity generation: Santa Barbara, California, University of California, Bren School of Environmental Management and Science, $194 \mathrm{p}$.

Diehl, T.H., 2011, Estimating forced evaporation from surface water, in Proceedings of the Third Thermal Ecology and Regulation Workshop, October 11-12, 2011, Maple Grove, Minnesota: Palo Alto, California, Electrical Power Research Institute, p. 23-1-23-10.

Diehl, T.H., Harris, M.A., Murphy, J.C., Hutson, S.S., and Ladd, D.E., 2013, Methods for estimating water consumption for thermoelectric power plants in the United States: U.S Geological Survey Scientific Investigations Report 2013-5188, 78 p. [Also available at http://pubs.usgs.gov/ $\operatorname{sir} / 2013 / 5188 /$.

DiPippo, Ronald, 2004, Second law assessment of binary plants generating power from low-temperature geothermal fluids: Geothermics, v. 33 , no. 5, p. 565-586, accessed July 28, 2013, at http://www.sciencedirect.com/science/ article/pii/S0375650504000094.

Drader, D., Jonsson, M.T., and Palsson, H., 2012, Improved power production efficiency of hydrothermal reservoirs using downhole pumps, in Proceedings of the ThirtySeventh Workshop on Geothermal Reservoir Engineering, January 30-February 1, 2012, Stanford, California: Stanford, California, Stanford University, SGP-TR-194, accessed April 23, 2013, at http://www.geothermal-energy. org/pdf/IGAstandard/SGW/2012/Drader.pdf. 
Dziegielewski, Ben, and Kiefer, J.C., 2010, Water conservation measurement metrics - Guidance report: American Water Works Association Water Conservation Division Subcommittee Report, submitted to The American Water Works Association Water Conservation Division Subcommittee: Denver, Colorado, 62 p., accessed July 28, 2013, at http://www.awwa.org/Portals/0/files/resources/resource\%20 dev\%20groups/tech\%20and\%20educ\%20program/ documents/WaterConservationMeasurementMetricsGuidance Report.pdf.

Eaton, Joe, 2012, Record heat, drought pose problems for U.S. electric power: National Geographic News, accessed April 25, 2013, at http://news.nationalgeographic.com/ news/energy/2012/08/120817-record-heat-drought-poseproblems-for-electric-power-grid/.

Edinger, J.E., Brady, D.K., and Geyer, J.C., 1974, Heat exchange and transport in the environment: Baltimore, Maryland, The Johns Hopkins University, Department of Geography and Environmental Engineering, Report No. 14 (No. NP-2900127), 137 p.

Efron, B., and Efron, B., 1982, The jackknife, the bootstrap and other resampling plans: Philadelphia, Society for Industrial and Applied Mathematics, v. 38, 92 p.

Electric Power Research Institute (EPRI), 2011, Program on technology innovation-Electricity use in the electric sector-Opportunites to enhance electric energy efficiency in the production and delivery of electricity, 2011 Technical Report: Palo Alto, California, EPRI, Final Report 1024651, accessed February 11, 2013, at http://www.pserc.wisc.edu/ documents/publications/special_interest_publications/ EPRI_Electricity_Use_Report_Final_1024651.pdf.

Esri, 2012, ArcGIS-Release 10.1: Redlands, California, Environmental Systems Research Institute.

Evapco, 2010, Cooling Towers-Free Cooling Operation: Taneytown, Maryland, Evapco Engineering Bulletin EB23D, April 16, 2010, 28 p., accessed August 20, 2013, at $h t t p: / / w w w . e v a p c o . e u / s i t e s / e v a p c o . e u / f i l e s / w h i t e$ papers/23-Free-Cooling-for-Cooling-Towers.pdf.

Evenson, E.J., Orndorff, R.C., Blome, C.D., Bohlke, J.K., Herschberger, P.K., Langenheim, V.E., McCabe, G.J., Morlock, S.E., Reeves, H.W., Verdin, J.P., Weyers, H.S., and Wood, T.M., 2012, Strategic directions for U.S. Geological Survey water science, 2012-2022-Observing, understanding, predicting, and delivering water science to the Nation: U.S. Geological Survey Open-File Report 2012-1066, 42 p.

Farnsworth, R.K., Thompson, E.S., and Peck, E.L., 1982, Evaporation atlas for the contiguous 48 United States: U.S. Department of Commerce, National Oceanic and Atmospheric Administration Technical Report No. 33.
Ferrero, R.C., Kolak, J.J., Bills, D.J., Bowen, Z.H., Cordier, D.J., Gallegos, T.J., Hein, J.R., Kelley, K.D., Nelson, P.H., Nuccio, V.F., Schmidt, J.M., and Seal, R.R., 2013, U.S. Geological Survey energy and minerals science strategy-A resource lifecycle approach: U.S. Geological Survey Circular 1383-D, $37 \mathrm{p}$.

Franco, Alessandro, and Villani, Marco, 2009, Optimal design of binary cycle power plants for water-dominated, medium-temperature geothermal fields: Geothermics, v. 38,

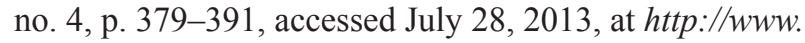
sciencedirect.com/science/article/pii/S0375650509000480. [Also available at $h t t p: / / d x$.doi.org/10.1016/j. geothermics.2009.08.001.]

Fry, J., Xian, G., Jin, S., Dewitz, J., Homer, C., Yang, L., Barnes, C., Herold, N., and Wickham, J., 2011, Completion of the 2006 National Land Cover Database for the conterminous United States: Photogrammetric Engineering and Remote Sensing, v. 77, no. 9, p. 858-864.

Fulford, J.M., and Sturm, T.W., 1984, Evaporation from flowing channels: American Society of Civil Engineers Journal of Energy Engineering, v. 110, no. 1, p. 1-10.

Golub, Miroslav, Kurevija, Tomislav, and Pravica, Zdravko, 2006, Maximum energy output of geopressured geothermal reservoirs in Croatia, in Frankovic, Bernard, ed., Rijeka: Hrvatski savez za energiju, 2006 International Congress Energy and Environment October 25-27, 2006, v. 2, p. 121-130, accessed August 20, 2013, at http://bib.irb.hr/ datoteka/264772.MAXIMUM_ENERGY_OUTPUT_OF_ GEOPRESSURED_GEOTHERMAL_RESERVOIRS_IN_ CROATIA.pdf.

Gulliver, J.S., and Stefan, H.G., 1986, Wind function for a sheltered stream: Journal of Environmental Engineering, v. 112 , no. 2 , p. 387-399.

Harbeck, G.E., Jr., 1964, Estimating forced evaporation from cooling ponds: Journal of the Power Division, ASCE, v. 90, no. 3, p. $1-10$.

Helsel, D.R., and Hirsch, R.M., 2002, Statistical methods in water resources: U.S. Geological Survey Techniques of Water-Resources Investigations, book 4, chap. A3, 524 p. [Also available at $h t t p: / / w a t e r . u s g s . g o v / p u b s / t w r i / t w r i 4 a 3 /$.

Hu, M.C., Pavlenco, G.F., and Englesson, G.A., 1978, Water consumption and costs for various steam electric power plant cooling systems: Research Triangle Park, North Carolina, U.S. Environmental Protection Agency, Industrial Environmental Research Laboratory, EPA-600/7-78-157, $129 \mathrm{p}$. 
Hu, M.C., Pavlenco, G.F., and Englesson, G.A., 1981, Executive summary for power plant cooling system water consumption and nonwater impact reports: Research Triangle Park, North Carolina, U.S. Environmental Protection Agency, Industrial Environmental Research Laboratory, EPA-600/S7-81-112, 19 p.

Huston, R.J., 1975, An overview of water requirements for electric power generation, in Gloyna, E.F., Herbert, H.W., and Howard, R.D., eds., Water management by the electric power industry: Austin, Texas, University of Texas at Austin, Center for Research in Water Resources, p. 39-49.

Hutson, S.S., comp., 2007, Guidelines for preparation of State water-use estimates for 2005: U.S. Geological Survey Techniques and Methods, book 4, chap. E1, 36 p., accessed August 23, 2013, at http://pubs.usgs.gov/tm/2007/tm4e1/ pdf/tm4-e1.pdf.

Hutson, S.S., Barber, N.L., Kenny, J.F., Linsey, K.S., Lumia, D.S., and Maupin, M.A., 2004, Estimated use of water in the United States in 2000: U.S. Geological Survey Circular 1268, 46 p. [Also available at http://pubs.usgs.gov/ circ/2004/circ1268/.]

International Atomic Energy Agency, 2009, Nuclear technology review 2009: Vienna, International Atomic Energy Agency, p. 110, accessed August 20, 2013, at http://www. iaea.org/Publications/Reports/ntr2009.pdf.

International Energy Agency, 2008, Combined heat and power-Evaluating the benefits of greater global investment: Paris, Organisation for Economic Co-Operation and Development and International Energy Agency, accessed February 27, 2013, at http://www.iea.org/publications/ freepublications/publication/chp_report.pdf.

Kagel, A., Bates, D., and Gawell, K., 2005, A guide to geothermal energy and the environment: Washington, D.C., Geothermal Energy Association, 75 p.

Kelly, B., 2006, Nexant parabolic trough solar power plant systems analysis - Task 2 - Comparison of wet and dry Rankine cycle heat rejection: Denver, Colorado, National Renewable Energy Laboratory, NREL/SR-550-40163, 28 p.

Kenny, J.F., Barber, N.L., Hutson, S.S., Linsey, K.S., Lovelace, J.K., and Maupin, M.A., 2009, Estimated use of water in the United States in 2005: U.S. Geological Survey Circular 1344, 52 p. [Also available at http://pubs.usgs.gov/ circ/1344/.]

Krivoruchko, Konstantin, 2012, Empirical bayesian kriging: ArcUser, v. 15 , no. 4, p. 6-10.

Larson, D., Lee, C., Tellinghuisen, S., and Keller, A., 2007, California's energy-water nexus-Water use in electricity generation: Southwest Hydrology, September/October, p. 20-22.
Leung, Paul, and Moore, R.E., 1970, Water consumptive determination for steam power plant cooling towers-A heat and mass balance method: Combustion, v. 42 , no. 5 , p. 14-23.

Leung, Paul, and Moore, R.E., 1971, Water consumption study for Navajo plant: Journal of the Power Division, v. 97, no. 4, p. $749-766$.

MacKichan, K.A., 1951, Estimated water use in the United States, 1950: U.S. Geological Survey Circular 115, 13 p. [Available at http://pubs.usgs.gov/circ/1951/circ115/.]

MacKichan, K.A., 1957, Estimated water use in the United States, 1955: U.S. Geological Survey Circular 398, 18 p. [Available at http://pubs.er.usgs.gov/publication/cir398.]

MacKichan, K.A., and Kammerer, J.C., 1961, Estimated use of water in the United States, 1960: U.S. Geological Survey Circular 456, 44 p. [Available at http://pubs.er.usgs.gov/ publication/cir456.]

Macknick, J., Newmark, R., Heath, G., and Hallett, K.C., 2011, A review of operational water consumption and withdrawal factors in electricity generating technologies: Golden, Colorado, National Renewable Energy Laboratory, Technical Report NREL/TP-6A20-50900, 21 p., accessed August 19, 2013, at http://www.nrel.gov/docs/ fy11osti/50900.pdf.

Majewski, W., and Miller, D.C., 1979, Predicting effects of power plant once-through cooling on aquatic systems-A state-of-the-art report of IHP Working Group 6.2 on the effects of thermal discharges: Paris, France, UNESCO, Technical papers in hydrology 20, $171 \mathrm{p}$.

Marley, 2012, Operating cooling towers in freezing weather: Bellvue, Washington, Olympic Engineered Sales, Inc., Marley technical report H-003B, 8 p., accessed August 20, 2013, at http://olyengsales.com/techreports.html.

Maulbetsch, J.S., and DiFilippo, M.N., 2006, Cost and value of water use at combined-cycle power plants: Prepared for California Energy Commission, Public Interest Energy Research Program, PIER Energy-Related Environmental Research, CEC-500-2006-034, [variously paged], accessed July 30, 2013, at http://www.energy. ca.gov/2006publications/CEC-500-2006-034/CEC-5002006-034.PDF.

Maulbetsch, J.S., and DiFilippo, M.N., 2010, Performance, cost, and environmental effects of saltwater cooling towers: Prepared for California Energy Commission, Public Interest Energy Research Program, Public Interest Energy Research Program Final Project Report, CEC-500-2008043, accessed August 19, 2014, at http://www.energy. ca.gov/2008publications/CEC-500-2008-043/CEC-5002008-043.PDF. 
McJannet, D.L., Webster, I.T., and Cook, F.J., 2012, An areadependent wind function for estimating open water evaporation using land-based meteorological data: Environmental Modelling \& Software, v. 31, p. 76-83, accessed July 30, 2013, at http://www.sciencedirect.com/science/article/ pii/S1364815211002805. [Also available at $h t t p: / / d x . d o i$. org/10.1016/j.envsoft.2011.11.017.]

Mishra, G.S., Glassley, W.E., and Yeh, Sonia, 2011, Realizing the geothermal electricity potential-Water use and consequences: Environmental Research Letters, v. 6, no. 3, 8 p., accessed July 30, 2013, at http://m.iopscience.iop. org/1748-9326/6/3/034023/pdf/1748-9326_6_3_034023. $p d f$. [Also available at $h t t p: / / d x$.doi.org/10.1088/17489326/6/3/034023.]

Murkowski, Lisa, 2014, The energy-water nexus-Interlinked resources that are vital for economic growth and sustainability: Washington, D.C., 22 p., accessed August 19, 2014, at $h t t p: / / w w w . e n e r g y . s e n a t e . g o v / p u b l i c / i n d e x . c f m / f i l e s /$ serve?File_id=9d529812-659b-43a1-a2d1-ef0e67894636.

Murray, C.R., 1968, Estimated use of water in the United States, 1965: U.S. Geological Survey Circular 556, 53 p. [Also available at http://pubs.er.usgs.gov/publication/ cir556.]

Murray, C.R., and Reeves, E.B., 1972, Estimated use of water in the United States in 1970: U.S. Geological Survey Circular 676, 37 p. [Also available at http://pubs.er.usgs.gov/ publication/cir676.]

Murray, C.R., and Reeves, E.B., 1977, Estimated use of water in the United States in 1975: U.S. Geological Survey Circular 765, 39 p. [Also available at http://pubs.er.usgs.gov/ publication/cir765.]

National Oceanic and Atmospheric Administration, National Climatic Data Center, 2012a, National Solar Radiation Database (1991-2010), accessed July 3, 2013, at http:// www.ncdc.noaa.gov/data-access/land-based-station-data/ land-based-datasets/solar-radiation.

National Oceanic and Atmospheric Administration, National Climatic Data Center, 2012b, NOAA's 1981-2010 U.S. Climate Normals, accessed July 2, 2013, at http://www.ncdc. noaa.gov/data-access/land-based-station-data/land-baseddatasets/climate-normals/1981-2010-normals-data.

National Oceanic and Atmospheric Administration, National Climatic Data Center, [n.d.], Quality Controlled Local Climatological Data database, accessed March 8, 2013, at $h t t p: / / w w w . n c d c . n o a a . g o v / d a t a-a c c e s s /$ land-basedstation-data/land-based-datasets/quality-controlled-localclimatological-data-qclcd.
National Research Council, 2002, Estimating water use in the United States-A new paradigm for the National Water Use Information Program: Washington, D.C., National Academy Press, $176 \mathrm{p}$.

Pilz, J., and Spöck, G., 2007, Why do we need and how should we implement Bayesian kriging methods: Stochastic Environmental Research and Risk Assessment, v. 22, no. 5, p. $621-632$.

Rutberg, M., Delgado, A., Herzog, H., and Ghoniem, A., 2011, A system-level generic model of water use at power plants and its application to regional water use estimation, in Proceedings of the American Society of Mechanical Engineers, 2011 International Mechanical Engineering Congress and Exposition, Denver, Colorado, $11 \mathrm{p}$.

Sathyanathan, V.T., 2010, Running a coal fired boiler at the best efficiency: Bright Hub Engineering, accessed March 25, 2013, at http://www.brighthubengineering.com/powerplants/41375-running-a-coal-fired-boiler-at-the-bestefficiency/.

Soil Survey Staff, Natural Resources Conservation Service, United States Department of Agriculture, 2013, Web Soil Survey, accessed August 9, 2013, at http://websoilsurvey. nrcs.usda.gov/.

Solley, W.B., Chase, E.B., and Mann, W.B., IV, 1983, Estimated use of water in the United States in 1980: U.S. Geological Survey Circular 1001, 55 p. [Also available at http:// pubs.er.usgs.gov/publication/cir1001.]

Solley, W.B., Merk, C.F., and Pierce, R.R., 1988, Estimated use of water in the United States in 1985: U.S. Geological Survey Circular 1004, 82 p. [Also available at http://pubs. er.usgs.gov/publication/cir1004.]

Solley, W.B., Pierce, R.R., and Perlman, H.A., 1998, Estimated use of water in the United States in 1995: U.S. Geological Survey Circular 1200, 71 p. [Also available at $h t t p: / /$ pubs.er.usgs.gov/publication/cir1200.]

Stannard, D.I., Rosenberry, D.O., Winter, T.C., and Parkhurst, R.S., 2004, Estimates of fetch-induced errors in Bowenratio energy-budget measurements of evapotranspiration from a prairie wetland, Cottonwood Lake area, North Dakota, USA: Wetlands, v. 24, no. 3, p. 498-513, accessed July 30, 2013, at http://link.springer.com/ article/10.1672\%2F0277-5212(2004)024\%5B0498\%3AEO FEIB\%5D2.0.CO\%3B2\#.

Strauss, J.B., 1978, Comparison of model predictions and consumptive water use of closed cycle cooling system, Final Report, March-July 1978: Springfield, Virginia, Versar, Inc., EPA-600/7-78-206, [variously paged]. 
Stultz, S.C., and Kitto, J.B., eds., 1992, Steam, its generation and use (40th ed.): Barberton, Ohio, Babcock \& Wilcox, $131 \mathrm{p}$.

Templin, W.E., Herbert, R.A., Stainaker, C.B., Horn, Marilee, and Solley, W.B., 1999, National handbook of recommended methods for water data acquisition - Chapter $11 \mathrm{~J}-$ Thermoelectric power generation: U.S. Geological Survey, accessed August 22, 2013, at http://pubs.usgs.gov/ chapter11/chapter11J.html.

Texas Water Development Board, 2003, Power generation water use in Texas for the years 2000 to 2060-Final report: Austin, Texas, 141 p. plus appendixes.

The Cooling Tower Company, L.C., 2005, Installation, operation and maintenance manual for Series TCI cooling tower: TCI Cooling, Tower Revision 1, 35 p.

United Nations Environment Programme, Division of Technology, 2006, Energy efficiency guide for industry in Asia: United Nations Publications, 17 p., accessed March 25, 2013, at http://www.energyefficiencyasia.org/docs/ee_ modules/Chapter-Cooling\%20Towers.pdf.

U.S. Department of Energy, 2009, Concentrating solar power commercial application study - Reducing water consumption of concentrating solar power electricity generation: Washington, D.C., U.S. Department of Energy, Report to Congress, $24 \mathrm{p}$.

U.S. Department of Energy, Energy Information Administration, 2001, 2000 Form EIA-860 database, accessed August 20, 2013, at http://www.eia.gov/electricity/data/ eia860/index.html.

U.S. Department of Energy, Energy Information Administration, 2006a, 2005 Form EIA-767 database, power plant operations report, accessed July 26, 2013, at $h t t p: / / w w w . e i a$. gov/electricity/data/eia767/.

U.S. Department of Energy, Energy Information Administration, 2006b, 2005 Form EIA-860 database, power plant operations report, accessed July 21, 2011, at http://www.eia. gov/electricity/data/eia860/.

U.S. Department of Energy, Energy Information Administration, 2006c, 2005 Form EIA-923 database, power plant operations report, accessed July 26, 2013, at http://www.eia. gov/electricity/data/eia923/.

U.S. Department of Energy, Energy Information Administration, 2009, 2008 Form EIA-860 database, accessed January 22, 2013, at http://www.eia.gov/electricity/data/eia860/ index.html.

U.S. Department of Energy, Energy Information Administration, 2011a, 2010 Form EIA-860 database, annual electric generator report, accessed January 22, 2013, at http://www. eia.gov/electricity/data/eia860/index.html.
U.S. Department of Energy, Energy Information Administration, 2011b, 2010 Form EIA-923 database, power plant operations report, accessed January 22, 2013, at $h t t p: / / w w w$. eia.gov/electricity/data/eia923/.

U.S. Department of Energy, Energy Information Administration, 2013, Electric Power Annual 2011, accessed August 21, 2013, at http://www.eia.gov/electricity/annual/ pdflepa.pdf.

U.S. Department of Energy, National Energy Technology Laboratory, 1999, DOE/FE-0400, Market-based advanced coal power systems - Final report May 1999, 374 p., accessed August 21, 2013, at http://www.netl.doe.gov/technologies/ coalpower/turbines/refshelf/igcc-h2-sygas/marketbased_ systems_report.pdf.

U.S. Department of Energy, National Energy Technology Laboratory, 2007a, Cost and performance baseline for fossil energy plants, DOE/NETL-2007/1281, Volume 1: Bituminous coal and natural gas to electricity final report (Original Issue Date, May 2007), accessed February 11, 2013, at http://www.netl.doe.gov/energy-analyses/pubs/BitBase FinRep_2007.pdf.

U.S. Department of Energy, National Energy Technology Laboratory, 2007b, Coal power plant database, accessed August 20, 2013, at http://www.netl.doe.gov/energy-analyses/ pubs/cppd/XLS\%20CPPDB\%202005\%20-\%20Public.zip.

U.S. Department of Energy, National Energy Technology Laboratory, 2010, Estimating freshwater needs to meet future thermoelectric generation requirements, 2010 update: U.S. Department of Energy, DOE/NETL400/2010/1339, 109 p., accessed August 20, 2013, at http:// www.netl.doe.gov/energy-analyses/refshelf/PubDetails. aspx? Action=View\&PubId $=335$ (index page) or $h t t p: / / w w w$. netl.doe.gov/energy-analyses/pubs/2010_Water_Needs_ Analysis.pdf (manuscript).

U.S. Environmental Protection Agency, 2006, National Electric Energy Data System (NEEDS) 2006, accessed March 27, 2013, at http://www.epa.gov/airmarkets/ progsregs/epa-ipm/BaseCase2006.html (index page), http://www.epa.gov/airmarkets/progsregs/epa-ipm/docs/ v410/NEEDSv410.zip (Excel spreadsheet database), and http://www.epa.gov/airmarkets/progsregs/epa-ipm/docs/ v410/Guide_to_NEEDSv410.pdf and http://www.epa.gov/ airmarkets/progsregs/epa-ipm/docs/v410/Chapter4.pdf (supporting documentation).

U.S. Environmental Protection Agency, 2007a, Emissions \& Generation Resource Integrated Database (eGRID), accessed January 22, 2013, at http://www.epa.gov/ cleanenergy/energy-resources/egrid/index.html\#download. 
U.S. Environmental Protection Agency, 2007b, National Hydrography Dataset Plus_-NHDPlus, Version 1.1: Washington D.C., U.S. Environmental Protection Agency, Office of Water, vector/raster digital data.

U.S. Environmental Protection Agency, [n.d.], Enforcement and Compliance History Online (ECHO), accessed January 22, 2013, at http://www.epa-echo.gov/echo.

U.S. Geological Survey, 2013, Water basics glossary, accessed September 2, 2014, at http://water.usgs.gov/water-basics_ glossary.html.

U.S. Government Accountability Office, 2009, Energy-water nexus-Improvements to Federal water use data would increase understanding of trends in power plant water use-Report to the Chairman, Committee on Science and Technology, House of Representatives: GAO-10-23, 73 p., accessed July 31, 2013, at http://www.gao.gov/new.items/ d1023.pdf.
U.S. Nuclear Regulatory Commission, 2009, 2009-2010 Information Digest, NUREG-1350, 21, 194 p., accessed August 20, 2013, at http://www.nrc.gov/reading-rm/doccollections/nuregs/staff/sr1350/v21/sr1350v21.pdf.

U.S. Nuclear Regulatory Commission, 2010, 2010-2011 Information Digest, NUREG-1350, 22, 191 p., accessed August 21, 2013, at http://pbadupws.nrc.gov/docs/ML1024/ ML102460490.pdf.

U.S. Nuclear Regulatory Commission, 2011, 2011-2012 Information Digest, NUREG-1350, 23, 186 p., accessed August 21, 2013, at http://www.nrc.gov/reading-rm/doccollections/nuregs/staff/sr1350/v23/sr1350v23.pdf.

Ward, G.H., Jr., 1980, Accuracy of Harbeck diagram for forced evaporation: Journal of the Energy Division, v. 106, no. 1, p. 23-31.

Webster, I.T., and Sherman, B.S., 1995, Evaporation from fetch-limited water bodies: Irrigation Science, v. 16, p. 53-64. 


\section{Glossary}

A

alternative water Water used at thermoelectric power plants as an alternative to freshwater; includes reclaimed water such as treated effluent from sewage treatment plants, groundwater that is unsuitable for drinking or irrigation because it is high in salts or other impurities, and seawater.

\section{B}

blowdown Water discharged from the cooling system to dispose of accumulating dissolved solids.

boiler efficiency The ratio between the amount of heat used to generate steam and the total heat content of the fuel that is consumed.

brackish water Water with a dissolvedsolids concentration between 1,000 and 10,000 milligrams per liter.

\section{C}

capacity factor The total power produced in a given period divided by the product of the net unit capacity and the given time period.

condenser duty The amount of waste heat delivered to the cooling system through the condenser.

condenser range The increase in cooling water temperature as it passes through the condenser.

cooling system A system that removes waste heat from a power plant condenser and transfers it to the atmosphere.

cooling-system type The technology used to dissipate condenser duty to the atmosphere.

cycles of concentration The ratio of dissolved solids in the [circulating and] blowdown water to dissolved solids in the makeup water.

\section{D}

design range The condenser range under design conditions, i.e., with the plant running at full power.

dry cooling system A cooling system that condenses steam and transfers the waste heat to the atmosphere without the consumption of water.

\section{E}

evaporation ratio The ratio of the amount of heat transferred to the air as evaporation to the condenser duty.

\section{$\mathbf{F}$}

forced evaporation The increase in evaporation of surface water due to the added heat of discharged cooling water.

freshwater Water that contains less than 1,000 milligrams per liter of dissolved solids.

\section{G}

generation type The type of technology used to generate electricity in a given unit or plant, including the energy source and prime mover.

\section{H}

heat budget A summation of all significant flows of heat into and out of a system such as a power plant.

high range As applied to condensers, having a condenser range greater than 25 degrees Fahrenheit $\left({ }^{\circ} \mathrm{F}\right)$.

\section{L}

linked heat and water budget A summation of all significant flows of heat and water into and out of a power plant, linked by converting energy flows embodied in water flow and evaporation into their equivalent volume flow rates of liquid water.

\section{M}

makeup Water added to the cooling system to replace evaporation and blowdown.

medium range As applied to condensers, having a condenser range between 10 and 25 degrees Fahrenheit $\left({ }^{\circ} \mathrm{F}\right)$.

\section{N}

natural evaporation In contrast to forced evaporation, the evaporation of surface water due to heat from sources other than the power plant. 
net generation The amount of electricity generated by a power plant and transmitted. Net generation is the gross electrical energy generated minus electrical energy consumed in the plant by auxiliary equipment.

\section{0}

once-through cooling system A cooling system in which the water is withdrawn from a surface-water source other than a recirculating pond to condense the steam used to generate electricity and that discharges the water back to surface water at a higher temperature.

$\mathbf{P}$

plant A facility that generates electricity from another source of energy such as fossil fuels, nuclear fission, geothermal energy, or solar radiation and heat.

prime mover In thermoelectric plants, the prime mover is the turbine that converts the energy in heated gases to mechanical energy.

pumpage As applied to cooling systems, the amount of water moved by pumps.

\section{$\mathbf{R}$}

recirculating cooling system A cooling system in which water is circulated through condensers, cooled, and then re-used in the same process.

\section{S}

saline water Water that contains 1,000 milligrams per liter or more of dissolved solids. surface-water cooling system A coolingsystem type that transfers heat from a condenser to the atmosphere through evaporation at the free surface of an open body of water. In addition to evaporation, some heat leaves the water surface through conduction and radiation.

\section{$\mathbf{T}$}

thermal efficiency The percentage of fuel heat used to produce electricity.

thermoelectric Relating to the generation of electric power from heat.

thermoelectric water consumption The water evaporated or incorporated into byproducts as a result of the production of electricity from heat.

thermoelectric water withdrawal The water removed from groundwater or surface water for use in a thermoelectric power plant.

\section{W}

waste heat Heat used but not converted to electricity in a thermoelectric plant.

water budget A summation of all significant flows of water into and out of a system such as a power plant.

wet cooling tower A cooling-system type that transfers heat from a condenser to the atmosphere primarily through evaporation, and to a lesser extent through conduction, in a natural-draft or mechanical-draft tower.

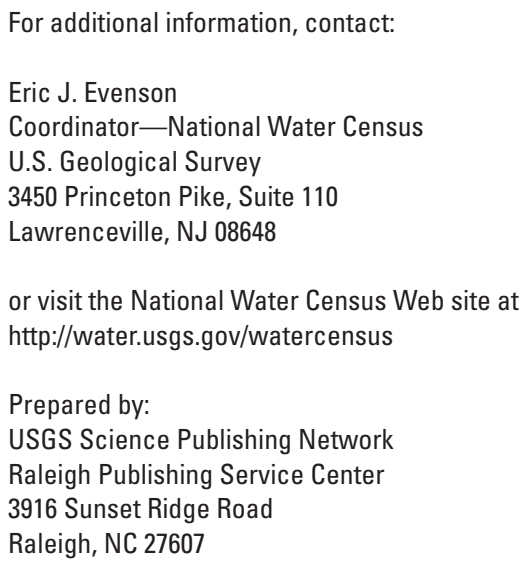



